\title{
Erard Harps in the Collection of the Czech Museum of Music
}

\section{Daniela Kotašová}

Abstract: The present harp collection of the National Museum - Czech Museum of Music contains Erard pedal harps from various periods of that famed Parisian company's activity. In creating musical instruments, Sébastian Erard built upon the work of G. Cousineau and C. Groll and became the most successful manufacturer of double-action pedal harps with a fourchette (fork) mechanism (mécanique à fourchettes et à double mouvement). Erard's work as an instrument maker influenced not only the historical development of the harp, but also the work of other instrument makers. In Bohemia, the Czech harp maker Alois Červenka (1858-1938) built upon Erard's work with great success. The Erard harps in the collection of the Czech Museum of Music document the Czech socio-cultural context in which the harps of the French instrument maker were used from the late nineteenth century until the middle of the twentieth.

Key words: Sébastien Erard, harp, Czech Museum of Music instrument collection, pedal harp, singleaction pedal harp, double-action pedal harp, musical instrument manufacturers, decorating of musical instruments

\section{Introduction}

The current harp collection at the National Museum - Czech Museum of Music (NM-ČMH) contains a total of sixty-three specimens, ${ }^{1}$ and the set of pedal harps and hook harps represents the most numerous group. ${ }^{2}$ The products of French manufacturers are the most

This work was financially supported by the Ministry of Culture of the Czech Republic (DKRVO 2018/39, National Museum, 00023272).

I wish to thank everyone who has contributed advice, comments, or other valuable assistance towards the writing of this article, namely Panagiotis Poulopoulos (Deutsches Museum München), Anne-Emmanuelle Ceulemans (Musée des Instruments de Musique de Bruxelles), Fanny Guillaume-Castel, Roberta Scarzello (Museo dell’Arpa Victor Salvi, Piasco), Rudolf Hopfner (Sammlung alter Musikinstrumente - Kunsthistorisches Museum Wien), Michael Mullen (Royal College of Music in London), Lenka Stehnová (Dvůr Králové nad Labem Municipal Museum) and my colleagues from the National Museum - Czech Museum of Music (hereinafter the NM-ČMH). 1) For details about the historical development of the European harp from the Renaissance until the early twentieth century, see DROYSEN-REBER, Dagmar: Europäische Harfen von der Renaissance bis in das frühe 20. Jahrhundert im Überblick, in: Harfen des Berliner Musikinstrumenten-Museums, Staatliches Institut für Musikforschung, Preußischer Kulturbesitz, Berlin 1999, pp. 9-77 (hereinafter DROYSEN-REBER 1999).

2) Cf. the overview of all types of harps in the collection of the NM-ČMH. KOTAŠOVÁ, Daniela: Háčkové harfy z pozůstalosti Marie Zunové-Skalské (Hook Harps from the Estate of Marie Zunová-Skalská), Opus musicum, vol. 47, 2015, no. 5, p. 52. 
plentifully represented, while just under half as many are Czech products, and there is are comparable numbers of harps made in Austria. ${ }^{3}$

The set contains five Erard harps, which represent nearly $8 \%$ of the harps in the collection. For example, there is a collection of a comparable quantity at a museum of musical instruments in Brussels, ${ }^{4}$ which is the nearest to Erard's centre of activity. It is noteworthy that the Prague collection does not possess any stringed keyboard instrument made by Erard, unlike the collections in Vienna or Berlin, for example. ${ }^{5}$

\section{Pedal Harps in NM-ČMH}

\begin{tabular}{|l|l|l|l|}
\hline Manufacturer & Place & Dating & Inv. no. \\
\hline J. R. Storck? & Paris (?) & $1780 s-$ '90s & E $1997^{7}$ \\
\hline Erard frères, No. 22 & Paris & 1817 & E 88 \\
\hline H. P. Naderman, No. 162 & Paris & 1818 & E 1995 \\
\hline H. (?) Naderman & Paris & early $19^{\text {th }}$ century & E 89 \\
\hline E. Challiot, No. 234 & Paris & $1^{\text {st }}$ half of the $19^{\text {th }}$ century & E 2010 \\
\hline E. Challiot & Paris & $1^{\text {st }}$ half of the $19^{\text {th }}$ century & E 2009 \\
\hline F. Brunner, No. 19 & Vienna & $1^{\text {st }}$ third of the $19^{\text {th }}$ century & E 1999 \\
\hline F. Brunner, No. 31 & Vienna & $1^{\text {st }}$ third of the $19^{\text {th }}$ century & E 2005 \\
\hline F. Brunner, No. 32 & Vienna & $1^{\text {st }}$ third of the $19^{\text {th }}$ century & E 1532 \\
\hline F. Brunner, No. 49 & Vienna & $1^{\text {st }}$ third of the $19^{\text {th }}$ century & E 1502 \\
\hline J. A. Stumpff & London & $1^{\text {st }}$ third of the $19^{\text {th }}$ century & E 2008 \\
\hline
\end{tabular}

3) Attention was drawn in 2016 to the collection of four single-action pedal harps built by the Viennese instrument maker Franz Brunner (1786-1840): KOTAŠOVÁ, Daniela: Harfy Franze Brunnera ve fondu Českého muzea hudby / Harps Made by Franz Brunner in the Collection of the Czech Museum of Music, Musicalia, vol. 8, 2016, nos. 1-2, pp. 78-85 (Czech version), pp. 86-94 (English version) (hereinafter KOTAŠOVÁ 2016).

4) According to a written message from Fanny Guillaume-Castel dated 16 April 2018, the Musée des Instruments de Musique in Brussels has the following Erard harps in its collection: a single-action Empire model without a serial number, Paris 1789, 40 strings, 8 pedals (inv. no. JT005); double-action No. 2672, Greek model, London 1819, 43 strings, 8 pedals (inv. no. 3952); double-action No. 1883, Gothic model, Paris 1880, 47 strings, 8 pedals (inv. no. 2487); double-action No. 3620, Gothic model, Paris 1910, 47 strings, 7 pedals (inv. no. 3631); double-action No. 5983, Gothic model, London 1880s, 46 strings, 8 pedals (inv. no. 2008.014). The museum also has a noteworthy collection of sixteen Erard stringed keyboard instruments. For more details, see http://carmentis.kmkg-mrah.be [accessed on 4 May 2018].

5) The Viennese collection contains two pianofortes: Paris 1853 (inv. no. SAM 594); Paris 1861 (inv. no. SAM 1200). - E-mail from Rudolf Hopfner [15 March 2018]; The Berlin museum has two Erard harpsichords: Paris 1896, serial no. 75899 (inv. no. 4924); Paris 1889 (inv. no. 5191) and an Erard pianofortes, London ca. 1850, serial no. 2761 (inv. no. 4564). - DROYSEN-REBER, Dagmar - RESTLE, Konstantin: Berliner Musikinstrumenten-Museum, Bestandkatalog der europäischen Musikinstrumente 1888-1993, Staatliches Institut für Musikforschung, Preußischer Kulturbesitz, Berlin 1993, pp. 356, 358, 408.

6) The instruments are listed in chronological order, and the datings of the other harps were taken from publications; see ČİŽEK, Bohuslav: Hudebnínástroje evropské hudební kultury (Musical Instruments of European Musical Culture), Aventinum, Prague 2002, pp. 42-43 (hereinafter ČÍŽEK 2002); MÜLLER, Miloš: Jan Křtitel Krumpholtz, National Library, Prague 1999, pp. 133-135 (hereinafter MÜLLER).

7) For details about the harp with the inventory number E 1997, see KOTAŠOVÁ, Daniela: Die Pedalharfe eines unbekannten Instrumentenbauers aus der Sammlung von Marie Zunová-Skalská, Phoibos - Zeitschrift für Zupfmusik https://openjournals.uni-bayreuth.de/index.php/phoibos (forthcoming). 


\begin{tabular}{|l|l|l|l|}
\hline Manufacturer & Place & Dating & Inv. no. \\
\hline S. Erard, No. 3574 & London & 1824 & E 1994 \\
\hline Erard frères, No. 993 & Paris & 1825 & E 2004 \\
\hline E. Klíčník & Prague & ca. 1855-1857 & E 700 \\
\hline S. and P. Erard, No. 6147 & London & 1856 & E 2003 \\
\hline Erard, No. 2284 & Paris & 1892 & E 2425 \\
\hline anonymous & $?$ & $19^{\text {th }}$ century & E 1996 \\
\hline anonymous & ? & $19^{\text {th }}$ century & E 1998 \\
\hline A. Červenka & Prague & before $1895(?)$ & E 2800 \\
\hline A. Červenka & Prague & ca. 1900 & E 2638 \\
\hline
\end{tabular}

An Erard harp has been found in the Czech Republic in the collection of the Municipal Museum in Dvůr Králové nad Labem, where there is a Greek model of an Erard frères singleaction pedal harp No. 817 dated 1822. ${ }^{8}$ Two Erard pianos played by Ludwig van Beethoven in the early nineteenth century represent important cultural artefacts under the care of the state-administrated castle in Hradec nad Moravicí. ${ }^{9}$

\section{Current state of research}

Some of the first studies in Czech about Erard were published in 1894 in Otto's Educational Dictionary ${ }^{10}$ and in Pazdírek's Instructional Musical Dictionary. ${ }^{11}$ Other Czech texts about this manufacturer are conceived only in general terms or fragmentarily. ${ }^{12}$ Bohuslav Čížek was first to devote a relatively large amount of attention to Erard, initially within the framework of general discussion of musical instruments in collections of the NM- $\check{C} \mathrm{MH}$ and other institutions. ${ }^{13} \mathrm{He}$ wrote more detailed biographical information within the context of historical pianos in Bohemia and Moravia. ${ }^{14}$ No other Czech studies about Erard and his work have been found. On the other

8) Inscription on the harp: "Érard Frères. par brevet d'invention No 817. / Facteurs de Forte Piano \& de Harp du Roi / desés Menue Plaisir Dela Cour Imperiale de Russie. / de S. A. S. Monseigneurte Duc d’Orléans et desa famille Rue du Mail Nos 13 \& 21 à Paris."

9) Erard frères square piano No. 37, Paris 1803 ? (inv. no. HM 00614); Erard frères pianoforte, No. 143, Paris 1803 (inv. no. HM 00613). For details, see ČÍŽEK, Bohuslav: Historické klavíry v Čechách a na Moravé (Historical Pianos in Bohemia and Moravia), Togga, Prague 2010, pp. 72-74 (hereinafter ČÍŽEK 2010).

10) Ottův slovník naučný. Ilustrovaná encyklopedie obecných vědomostí (Otto’s Educational Dictionary. An Illustrated Encyclopaedia of General Knowledge), vol. 8, J. Otto, Prague 1894, p. 690. Accessed from http:// www.pdfknihy.maxzone.eu/books/OSN/otto08.pdf [accessed on 21 May 2018].

11) Pazdírkův hudebni slovník naučný II., část osobní (Pazdírek’s Instructional Musical Dictionary II, biographical section), vol. 1, Ol. Pazdírek, Brno 1937, p. 238.

12) ZUNOVÁ, Marie: $O$ harfě (About the Harp), Oldřich Blecha, Plzeň 1926, p. 3; HUTTER, Josef: Hudební nástroje (Musical Instruments), František Novák, Prague 1945, pp. 129-130; MÜLLER, op. cit. in footnote no. 6, pp. 118-119; The important Czech organologist Pavel Kurfürst briefly mentions Sébastien Erard in the context of "keyboard chordophones"; see KURFÜRST, Pavel: Hudební nástroje (Musical Instruments), Togga, Prague 2002, pp. 636, 638, 639.

13) ČÍŽEK 2002, op. cit. in footnote no. 6, pp. 43-44.

14) Unfortunately, the book was not conceived to allow for the listing of sources from which the author drew information - ČÍŻEK 2010, op. cit. in footnote no. 9, p. 72. 
hand, some Czech experts like to emphasise that Jan Křtitel Krumpholtz (1747-1790) played a personal role in the structural designs and changes to the harp predating Erard..$^{15}$

Reliable information about the Erard family of instrument makers is available in scholarly literature in various languages. Apart from the well-researched entries in lexicographical works with references to other studies, ${ }^{16}$ there have been a number of important new studies in recent decades. ${ }^{17}$ A publication by a team of authors led by the French musicologist, organologist, pedagogue, and curator Robert Adelson reports on the findings of a study of the recently discovered archives of the firm Erard. The first part deals with inventions, business dealings, and correspondence with composers and performers, and the second part is concerned with family correspondence. ${ }^{18}$ Unfortunately, most of the listed titles are very difficult to access in the Czech Republic.

Foreign specialists are examining this question not only from an organological point of view, ${ }^{19}$ but also from the perspectives of other related fields and disciplines. At present, a multiyear project of research scholars in Munich is drawing to a conclusion, ${ }^{20}$ and among its most recent outcomes has been a presentation of interdisciplinary research in the field of the conservation and restoration of Erard harp no. 2631, an object in the collection

15) E.g. MÜLLER, op. cit. in footnote no. 6, p. 118.

16) GÉTREAU, Florence: Erard, in: Die Musik in Geschichte und Gegenwart, Personalteil 6, ed. L. Finscher, Stuttgart 2001, $2^{\text {nd }}$ ed., pp. 391-396 (hereinafter GÉTREAU); GRIFFITHS, Ann - MACNUTT, Richard: Erard, in: The New Grove Dictionary of Music and Musicians. $2^{\text {nd }}$ ed., Vol. 8, ed. S. Sadie, Macmillan Publishers Limited 2002, New York, 2002, pp. 276-279 (hereinafter GRIFFITHS - MACNUTT).

17) E.g. FRICK, Rudolf: 1794-1994. Bemerkungen zum Stand der Erard-Forschung, in: Sébastien Erard: Ein europäischer Pionier des Instrumentenbaus. Internationales Erard-Symposium, Michaelsteiner Konferenzberichte, Bd. 48, Michaelstein 1994; FRICK, Rudolf: Die schweizerischen Ursprünge der Familie Erard, in: Sébastien Erard: Ein europäischer Pionier des Instrumentenbaus. Internationales Erard-Symposium, Michaelsteiner Konferenzberichte, Bd. 48, Michaelstein 1994, pp. 15-18 (hereinafter FRICK); ADELSON, Robert - BARTHEL, Laure - FOUSSARD, Michel et al.: Erard and the Invention of the Modern Harp, 1811-2011, Musée du Palais Lascaris, Nice 2011.

18) ADELSON, Robert - ROUDIER, Alain - NEX, Jenny - BARTHEL, Laure: History of the Erard Piano and Harp in Letters and Documents, 1785-1959, Cambridge University Press, Cambridge 2015.

19) E.g. RENSCH, Roslyn: The late eighteenth and early nineteenth centuries - Erard. Harps and Harpists, Bloomington, Indiana University Press, $2^{\text {nd }}$ edition 2007, pp. 147-150 (hereinafter RENSCH); PARKER, Mike: The Eighth Pedal, Fact or Fiction?, 2008, accessed from http://www.harpspectrum.org/historical/the_eighth_ pedal.shtml [accessed on 27 Feb. 2018]; WOLF, Beat: „Vom Kniff zum Tritt". Die Chromatisierung der Harfe, Schaffhausen 2009, pp. 3-4, accessed from http://www.beatwolf.ch/Portals/14/pdf/knifftritt_2009.pdf [accessed on 22 Mar. 2018] (hereinafter WOLF); BALDWIN, Mike: The Inventor of the Double-Action Pedal Harp with Fourchettes: Erard versus Groll, London 2009, accessed from www.harpspectrum.org/historical/Erard\%20 versus\%20Groll.shtml [accessed on 25 Jan. 2018].

20) The project deals with the development of the early phase of the pedal harp (1780-1830) from musicological, historical, technological, social, and cultural perspectives. - POULOPOULOS, Panagiotis: A Creative Triangle of Mechanics, Acoustics and Aesthetics: The Early Pedal Harp (1780-1830) as a Symbol of Innovative Transformation. See the thesis at https://portal.volkswagenstiftung.de/search/projectPDF. do?projectId=7314 [accessed on 10 April 2018]; RICHTER, Luise: Untersuchung der Dekoration einer ErardDoppelpedalharfe; see http://www.deutsches-museum.de/forschung/forschungsbereiche/sammlungen/ restaurierungsforsch/pedalharfe/ [accessed on 10 April 2018]. 
of the Deutsches Museum München. Experts performed sonic analysis of an Erard harp, ${ }^{21}$ and there is ongoing discussion over priorities of research of "intangible values" (such as sound) at the risk of losing "tangible values" (e.g. material) $)^{22}$ etc.

In recent years, the topic of Erard harps has become a subject of interest for papers by students at several universities around the world. ${ }^{23}$ One of the first attempts to deal with the question of the manufacturing of musical instruments as a whole from a socioeconomic perspective was defended at a university in London in a doctoral dissertation focusing on research of musical instruments as an industrial product in London between 1760 and $1820 .{ }^{24}$ The incidence of the pedal harp in colonial Australia in the period from 1830 to 1866 was surveyed at the university in Adelaide. ${ }^{25}$ The previously unresearched topic of the cooperation between Erard's Paris and London branches from 1790 to 1810 on the manufacturing and sale of single-action pedal harps became the focus of a Masters' thesis in 2017 at the Sorbonne in Paris. ${ }^{26}$

\section{History of the company Erard and its role in the development of the harp}

Sébastien Erard ${ }^{27}$ (5 April 1752 Strasbourg - Passy 5 August 1831) was born as the fourth child of the cabinetmaker Louis-Antoine Erard (1685-1758) ${ }^{28}$ and his second wife Barbe Meyer.

21) POULOPOULOS, Panagiotis - PAMPLONA, Marisa - RICHTER, Luise - PLATH, Niko: Conservation Issues on Historical Pedal Harps: Preserving Tangible and Intangible Properties, in: Preservation of Wooden Musical Instruments: Ethics, Practice and Assessment. Proceedings of $4^{\text {th }}$ Annual Conference of the COST Action FP1302 WoodMusICK. Brussels, ed. P. Vandervellen, Muziekinstrumentenmuseum, 2017, pp. 69-72, see http://woodmusick.org/wp-content/uploads/Proceedings_WoodMusICK_BRS.pdf [accessed on 23 Mar. 2018] (hereinafter POULOPOULOS 2017).

22) DE BRUYN, Vera: "Material or sound?" - Risk-benefit Analysis in the Recording of Musical Instruments (an unpublished article presented at the Ringve Music Museum in Trondheim, Norway, during the conference CIMCIM The Nordic Countries, 24 - 31 August 2014). Cf. POULOPOULOS 2017, op. cit. in footnote no. 21, pp. 71-72.

23) E.g. BÜHL, Franciska: Untersuchung einer Erard-Doppelpedalharfe von 1820-1825, Bachelor's thesis, Technische Universität München (Studiengang Restaurierung, Kunsttechnologie und Konservierungswissenschaft), Munich 2014. Accessed from https://www.rkk.ar.tum.de/fileadmin/w00ble/ www/media_rkk/downloads/Diplom-_und_BA-Arbeiten/BuehL_2013_BA-Thesis_online.pdf [accessed on 20 Feb. 2018] (hereinafter BÜHL); WALTER, Sandra: Die Einfachpedalharfe No. 512 der Brüder Erard aus dem Couven-Museum Aachen, Untersuchungen zu Bestand, Zustand, historischer Kontextualisierung sowie Durchführung der Konservierung, Restaurierung und Neubesaitung, thesis, Fachhochschule Erfurt 2010. Thesis at https://www. fh-erfurt.de/kr/fileadmin/KR/Abschlussarbeiten/2010/Walter.pdf [accessed on 21 Mar. 2018].

24) NEX, Jennifer Susan: The Business of Musical-Instrument Making in Early Industrial London, Goldsmiths College, University of London 2013. Accessed from https://research.gold.ac.uk/9606/1/MUS_thesis_ Nex_2013.pdf [accessed on 19 Feb. 2018] (hereinafter NEX 2013).

25) HALLO, Rosemary Margaret: Erard, Bochsa and their impact on harp music-making in Australia (1830-1866): an early history from documents. University of Adelaide, Elder Conservatorium of Music, 2014. Also see https:// digital.library.adelaide.edu.au/dspace/handle/2440/86482 [accessed on 19 Feb. 2018].

26) GUILLAUME-CASTEL, Fanny: L'entreprise Erard: étude d'une entreprise basée à Paris et à Londres entre les années 1790 et 1810 à travers la fabrication et la vente des harpes, Université Paris 1 Panthéon-Sorbonne, History Department, Paris, June 2017. Information from e-mail correspondence with Fanny Guillaume-Castel dated 18 April 2018 (hereinafter GUILLAUME-CASTEL 2017).

27) The surname "Erard" also appears in archival documentation spelled as "Erhard".

28) Sébastien's family can be traced back to the territory of present-day Switzerland, where his grandfather Hubert died in Bassecourt near Delémont (Basel Diocese) in 1722. - BÜHL 2014, op. cit. in footnote no. 23, p. 20. FRICK, op. cit. in footnote no. 17, p. 16. 
Sébastien's father died when he was six, so this is apparently one reason why we cannot document his education. He may be assumed to have been raised in the community of experienced craftsmen - his uncles, cousins, and godfather, who were artisan cabinetmakers and goldsmiths, especially in the milieu of the church. It is possible that Sébastien's brothers may also have been in contact with the workshop of Gottfried Silbermann in Strasbourg and that he familiarised himself with the work of the younger members of the great organ building dynasty. ${ }^{29}$

In ca. 1768 he went to Paris and entered the services of the Duchess de Villeroy (17311816), who provided him with space for his workshop at her manor on the Rue de Bourbon. ${ }^{30}$ At Sébastien's request, his older brother Jean-Baptiste (1749-1826) came to Paris in $1781 .^{31}$ On 5 February 1785 Sébastien obtained a license from Louis XVI for making musical instruments, although he did not belong to the Paris manufacturers' guild.

On 1 January 1788, the Erard brothers founded the company that then began to operate under the name Erard frères. ${ }^{32}$ Sébastien took over the financial management. In 1792 he opened an affiliated business in London at the address 18 Great Marlborough Street, and in England he concentrated on manufacturing harps, all of which had been imported from France until then. In 1795 Sébastien returned to Paris, but from then on he alternated between the two places where he presented the results of the improvement of instruments and his inventions. He obtained patents both in England (16 June 1801 and in 1808) and in France (1802, 1806), and after several years of effort, on 2 November 1810 he obtained a patent on a double-action pedal harp with the fourchette (fork) mechanism (London patent no. 3332).

During the era of the First French Empire (Empire Français, 1804-1815), the brothers were appointed as court suppliers to the Emperor and King Napoleon Bonaparte. The first exhibition took place in 1819, and Erard was awarded gold medals for four pianos and two harps. In 1820 Erard purchased private headquarters - the Château de la Muette in Passy near Paris. ${ }^{33}$ Erard was also regarded as a master of organ repair.

Pierre Orphée Erard ${ }^{34}$ (10 March 1794 - 16 Aug. 1855), the son of Jean-Baptiste Erard and the nephew of Sébastien, received musical training and learned the English language. He took over management of the London branch on 17 May 1814, and he was in charge of it until 1829. He made contributions to the mechanical development of the piano and the harp both

29) GRIFFITHS - MACNUTT, op. cit. in footnote 16, p. 276.

30) At a different site, Erard built his oldest preserved instrument, designated in 1779 as a "clavecin mécanique". Today, the specimen is kept in Paris at the Musée de la Musique. - GÉTREAU, op. cit. in footnote no. 16, p. 391.

31) The literature gives various birthdates for Jean-Baptiste: 1745 (DROYSEN-REBER 1999, op. cit. in footnote no. 1, p. 299); 1750 - NOVAK CLINKSALE, Martha: Makers of the Piano: 1820-1860, Vol. 2, Oxford University Press, New York 1999, p. 118 (hereinafter NOVAK); 1749 (GÉTREAU, op. cit. in footnote no. 16, p. 391).

32) The Paris branch of the Erard brothers' company closed with the death of Jean-Baptiste on 9 April 1826. After that, Sébastien ran the company until his death.

33) In the inventory of the Château de la Muette in Passy, approximately 260 pictures of exceptional value have been preserved. It is noteworthy that no musical instruments were found at the chateau. For details, see: GRIFFITHS, Ann: Sébastien Erard. A Dynasty of Harpmakers, World Harp Congress Review, 2002. Accessed from http://www.adlaismusicpublishers.co.uk/pages/harpists/erard.htm [accessed on 14 Mar. 2018] (hereinafter GRIFFITHS 2002).

34) His exact name was Jean-Baptiste Orphée Pierre Erard. Cf. NOVAK, op. cit. in footnote no. 31, p. 118. 


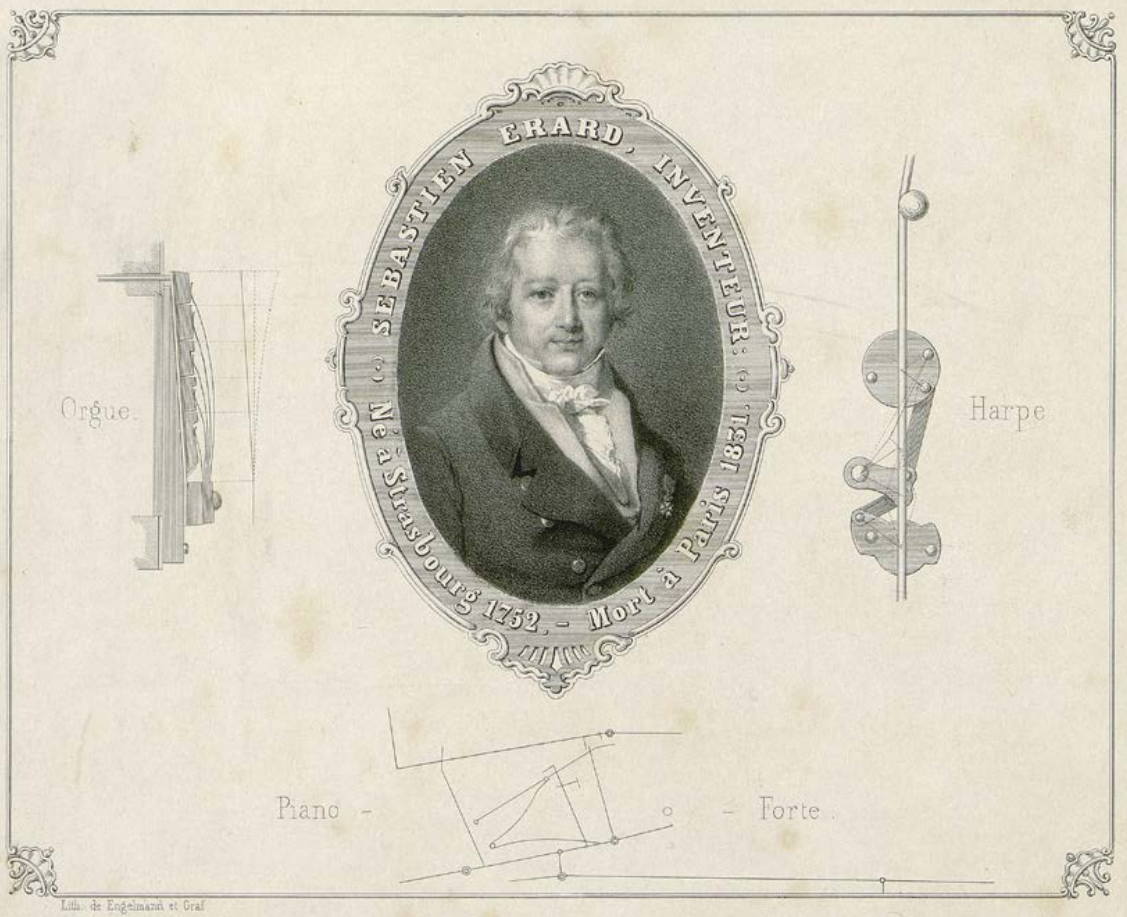

\section{Sébastien Erard}

Portrét, litografie Engelmann et Graf, [Paris] / Portrait, lithograph by Engelmann et Graf, [Paris] Kolem portrétu nápis „Sebastien Erard, Inventeur / Né à Strasbourg 1752 - Mort à Paris 1831“, doplněno schématy vynálezů týkajících se varhan, pianoforte a harfy / Inscription around the portrait: "Sebastien Erard, Inventeur / Né à Strasbourg 1752 - Mort à Paris 1831", with diagrams of inventions involving the organ, piano, and harp

NM-ČMH F 2299, pozůstalost Marie Zunové-Skalské / estate of Marie Zunová-Skalská

on his own and together with his uncle. After Sébastien's death, Jean-Baptiste Erard became the sole heir of the company in Paris and in London.

In 1834, Pierre Erard returned to Paris and married his cousin Camille Février (1813-1889), to whom the company passed upon his death in 1855. Madam Erard entrusted the London branch to M. Bruzaud, and she turned over the management of the Parisian firm to her brotherin-law Antoine Eugène Schaeffer (1802-1873). On 25 August 1873, Camille Erard entered into a business agreement with Amédée Blondel and continued to run the company under the name Erard et Cie (1873-1889). After Camille Erard's death, the company was inherited by her niece and adopted daughter, Madame de Franqueville. Erard's factory in London was sold at auction on 9 September 1890, and J. George Morley obtained a large share in the business. ${ }^{35}$ The London branch underwent a gradual decline until 1930. Blondel led the Paris factory until 1935 under the trademark Blondel $\mathcal{E} C^{i e}$ (Maison Erard). The company existed under the name Guichard

35) GRIFFITHS - MACNUTT, op. cit. in footnote no. 16, p. 278. 
$\mathcal{E} C^{i e}$ (Maison Erard) until 1959, when it merged with the company Gaveau. In May 1962 the company Pleyel was acquired as well. Schimmel bought the three companies in $1970 .{ }^{36}$

\section{Analysis of the Erard harps in the Czech Museum of Music collection}

At the end of the eighteenth century, several harp makers realised that the musical potential of the single-action pedal harp was limited, especially in comparison with stringed keyboard instruments (e.g. harpsichord, piano). In October 1794 in London, Sébastien Erard received his first patent on a harp with a fourchette (fork) mechanism with rotating prongs. It made possible the creation of the dual-action pedal harp - each of the seven pedals can be depressed to two lower positions. ${ }^{37}$ In this manner, all pitches with the same note name in all octaves can be raised by two semitones, something that was not possible with a single-action harp. The basic tuning of a double-action pedal harp is C-flat major.

The first instrument maker to experiment with a double-action harp model (1781) was Georges Cousineau (1733-1800). ${ }^{38}$ In 1782 he built an instrument with fourteen pedals and a crutch mechanism (mécanique à béquilles), but his invention of the double-action harp did not attract much attention. In London in 1807, Charles Groll (also spelled Gröll, 17701857) registered a patent on a double-action pedal harp, and Erard apparently had to buy the patent from him..$^{39}$ Erard was the first to promote the invention, patented in $1810 .{ }^{40}$ Although Erard did not invent this type of harp, he made it into a commercially successful product. The double-action harp is used in practise to this day, with certain structural improvements in modern concert harps, for example with the use of such materials as carbon fibre or nonstick coatings. ${ }^{41}$

Three of the five Erard harps from the NM-ČMH collection are still equipped with an original mechanical feature using an eighth pedal. Erard built these instruments until about the middle of the nineteenth century. The pedal, placed as the fourth from the left, opened and closed five sound holes fitted with shutters on the back of the body of the instrument. The purpose was to achieve various sound effects (crescendo, decrescendo, tremolo etc.). ${ }^{42}$ New findings from contemporary research show that before making a purchase, Erard's customers were apparently able to choose whether to order a harp with or without the system activated by the eighth pedal. ${ }^{43}$

36) GÉTREAU, op. cit. in footnote no. 16, p. 394.

37) The movement caused by depressing the pedal tightens and shortens the string, raising its tuning by a semitone (down one position) or a whole tone (down two positions). For example, depressing the pedal by one position changes $F$ flat to $F$, and from there on to $F$ sharp.

38) ZINGEL, Hans Joachim: Lexikon der Harfe, Laaber-Verlag, Regensburg 1977, p. 44.

39) WOLF, op. cit. in footnote no. 19, p. 3.

40) Erard sold the first specimen of a double-action pedal harp No. 1387 at Great Marlborough Street in London on 11 December 1811. The instrument still exists in a private collection in England. It has 43 strings, and its range is from E-flat ${ }_{2}$ to e-flat ${ }^{3}$. - GRIFFITHS 2002, op. cit. v pozn. 33.

41) WOLF, op. cit. in footnote 19, p. 4.

42) For details about the eighth pedal, see KOTAŠOVÁ 2016, op. cit. in footnote no. 3, pp. 81-82.

43) E-mail consultation with Fanny Guillaume-Castel dated 20 April 2018. 
Around the year 1800, a harp's decorations began to assume an ever increasing importance, especially as the presentation of a fashionable instrument that was in demand amongst the highest social classes. Erard's decorations are characterised by elements with palmette or zoomorphic motifs (e.g. sculpted ram heads or horse figures). If we compare the decorating of the crown of harp No. 22 with ram's head motifs (inv. no. E 88) with other instruments from this period, it is clear that Erard had been using the same decorations for older single-action instrument models unlike our double-action harp. Because the doubleaction mechanism was patented in 1810, it may be assumed that our specimen from 1817 was one of the first harps with the new double action and with decorations from older singleaction models. ${ }^{44}$ During the following period, the model known as the Gothic harp became the most commercially successful. Erard took inspiration for the new design from elements of the fashionable neo-Gothic style.

Pierre Erard strove to make harps with a stronger sound and a sturdier structure than pervious models. In his (advertising) book dated $1821,{ }^{45}$ he wrote, among other things, that Erard was completely redesigning the structure of the instrument's body, which he claimed to have structural faults. ${ }^{46} \mathrm{He}$ extended the soundboard of the double-action pedal harp by ca. 4-10 cm to allow the placement of forty-six strings on it (cf. harp No. 6147, inv. no. E 2003). He reinforced the bottom part of the body so much that its original thickness was roughly doubled. The openings for the pedals were cut directly into the rear wall of the body (cf. the pedal box of No. 2284, inv. no. E 2425). Pierre Erard obtained London patent no. 6962 on 18 December 1835. There are no other known structural changes to this type of harp.

The English Gothic model harp No. 6147 (inv. no. E 2003) from 1856 is characterised by the following elements:

- crown decorated with sculpted female figures - caryatids and angels playing historical musical instruments

- hexagonal design of the pillar and crown

- shutter mechanism with an eighth pedal

This type of harp, including its decorations, differs only slightly from the French model, newer by about half a century, of which Gothic harp No. 2284 (inv. no. E 2425) represents an illustrative example. This Parisian instrument is built without the shutter mechanism, and the pedals on the back of the base have a slightly bent shape. The two front feet of the base are formed in the shape of a lion cast of solid brass, the metal plate on the neck is embedded

44) Representing one of the first double-action Greek models is a harp four years older than our specimen, dating from 1821. It was built in London, it was assigned No. 3070, and it has 43 strings and 7 pedals (inv. no. E. 0997, Musée de la Musique, Paris). Accessed from http://collectionsdumusee.philharmoniedeparis.fr/doc/ MUSEE/0162312/harpe-a-double-mouvement [accessed on 23 April 2018].

45) ERARD, Pierre: The Harp: In its present improved State Compared with The Original Pedal Harp, Erard, London 1821.

46) The structure of the body did not actually exhibit any structural imperfections. Wolf points out that this erroneous evaluation persists even in current publications by experts - WOLF, op. cit. in footnote no. 19, p. 3 . 
directly into the shoulder etc. This model was still being made in serial production in Paris in the twentieth century. ${ }^{47}$

Of the Erard harps in the collection of the NM- $\check{C} \mathrm{MH}$, the instrument that underwent the greatest alterations was harp No. 3574 (inv. no. E 1994). Originally a Greek model harp built in England in 1824, it was restored at the turn of the nineteenth and twentieth centuries by Joseph George Morley (1847-1922). ${ }^{48}$ In addition, he replaced the pillar and the crown, and he probably also installed an original shutter mechanism into a harp with seven pedals.

In addition to the standard inscriptions on the sides of the neck, some Erard harps also have information recorded on other parts of the instrument. This may take the form of numbers, which appear most frequently, inscriptions, initials, stamp impressions, or handwriting. They are usually found under the neck, on the base, on the pedals etc. An example is the harp with the serial number 6147 (inv. no. E 2003), which has the number 6139 stamped on the bottom of the base with the letters $R$. B. and the handwritten comment Ant [?] Germany. So far, however, there has been no confirmation of any specific correlation or pattern between the two numbers on different parts of the harp. The "hidden" numerical data on metal and wooden parts are higher or lower than the "official" number engraved on the brass plate on the neck. These inscriptions probably document the division of labour during the construction of the harp by the manufacturer; the workers apparently marked the wooden parts to facilitate final assembly of the various parts of an instrument for a concrete model. ${ }^{49}$

\section{Descriptions of the harps ${ }^{50}$}

\section{- Erard frères, double-action pedal harp No. 22}

Greek model, Paris, 1817 (inv. no. E 88, acquisition no. 1105/51)

height $1710 \mathrm{~mm}$, number of strings 43 , string lengths ${ }^{51} 90$ to $1470 \mathrm{~mm}, 8$ pedals, range $\mathrm{E}_{1}-\mathrm{e}^{4}$ Inscriptions: "Par Brevet d’invention No. 22. / ERARD FRÈRES / Facteur de Forté Piano \& de Harpes du Roi / de Les Menus Plaisirs, \& de la Cour Impériale de Russie / Rue du Mail, Nos 13 \& 21, à Paris."

47) DROYSEN-REBER 1999, op. cit. in footnote no. 1, p. 256.

48) Joseph George Morley, the son of George Morley (1790-1852), registered his own company for manufacturing, tuning, and repairing harps in 1818 in London. In 1890, Joseph George took over the inventory and the reputation of the company Erard in London and opened a store and a workshop. He was the most important harp manufacturer in the Great Britain until the end of the First World War. He built an instrument with forty-eight strings, advertised as the "Largest Pedal Harp in the World". The demand for harps declined after the war, so the company concentrated on repairs and the manufacturing of small Irish harps. - Cf. ACKER, Anne Beetem: Morley, Robert, er Co. Accessed from http://www.oxfordmusiconline.com/grovemusic [accessed on 8 May 2018]; RENSCH, op. cit. in footnote no. 19, p. 179.

49) P. Poulopoulos is actively engaged in research in this direction. See POULOPOULOS, Panagiotis LEE, Julin: $\mathcal{A}$ Synergy of Form, Function and Fashion in the Manufacture of the Erard Harp, in: Wooden Musical Instruments: Different Forms of Knowledge, eds. M. A. Pérez - E. Marconi, published by the COST Action FP1302 WoodMusICK; forthcoming.

50) Detailed organological descriptions of each Erard harp in the NM-ČMH collection, including photographic documentation, are kept in the systematic records in the musical instrument department of the NM- ČMH. The present description is in abridged form.

51) Vibrating length of the shortest and longest strings. 
Origin: The harp was purchased in August 1817 for Count Albert Gyulay von Máros-Németh und Nádaska (1766-1835), ${ }^{52}$ a lieutenant field marshal of Hungarian nationality. ${ }^{53}$ According to other entries, the instrument was played by František Palacký’s wife Terezie, née Měchurová (1807-1860) and her sister Antonie (1810-1836). The harp was donated to the National Museum in 1898 by František Ladislav Rieger (1818-1903), son-in-law of the Czech historian František Palacký. ${ }^{54}$

Comparable specimen: Collection Camac Ancenis - Erard Frères, double-action harp No. 901, Empire model, Paris 1824, 43 strings, 8 pedals ${ }^{55}$

\section{- Sébastien Erard, double-action pedal harp No. 3574}

Greek model, London, 1824 (inv. no. E 1994, acquisition no. 14/64) height $1704 \mathrm{~mm}$, no. of strings 43, string lengths 112 to $1470 \mathrm{~mm}$, now 7 pedals, range $\mathrm{E}_{1}-\mathrm{e}^{4}$

Inscriptions: "Sebastian Erard's / Patent No. 3574 / 18 Great Marlborough Street London", "MAKER / By Special Appointment / to his Majesty and the / ROYAL FAMILY." "Restored by J. George Morley, Harp Maker from Erard's / C. Sussex Place, South Kensington, London"

Origin: The entry in the "Erard London Harp Ledgers"56 states that the harp was sold to Mr. Thomson of Liverpool in $1824 .{ }^{57}$ The harp came to the collection of the National Museum in 1961 from the estate of the harpist, teacher, and collector Marie Zunová-Skalská (1897-1961). Comparable specimens: Museo dell’Arpa Victor Salvi - Sébastien Erard, double-action pedal harp No. 2377, London 1812, 43 strings, $E_{0}-e^{6}, 8$ pedals (inv. no. SC0700) ${ }^{58}$; Deutsches Museum München - Sébastien Erard, double-action pedal harp No. 2631, London 1818, 8 pedals (inv. no. 16147) $)^{59}$

\section{- Erard frères, single-action pedal harp No. 993}

Empire model, Paris, 1825 (inv. no. E 2004, acquisition no. 61/61)

52) Details at http://www.napoleon-online.de/AU_Generale/html/gyulay.html [accessed on 24 April 2018]. 53) The entry in the archives reads: "rouge au lacqu[e] au Baron Bottmowiesky [?] pour le C[ompte?] Albert Giulay a Pest Hongri 22. 8. 1817”. - Erard Registres d’Atelier (Renseignés par Numéro de Série), accessed from http://archivesmusee.citedelamusique.fr/pleyel/archives.html [accessed on 9 Feb. 2018].

54) F. L. Rieger donated two harps to the Museum of the Kingdom of Bohemia in 1898; apart from the instrument identified above, there was also Naderman's single-action pedal harp (inv. no. E 89). - History Museum of the National Museum, department of Early Czech History, systematic records of the collection - liquidations.

55) Private collection Camac. La harpe de Marie-Antoinette à nos jours, Château d’Ancenis A partir du ler Jullet 2017. Accessed from https://www.camac-harps.com/wp-content/uploads/2017/06/tresors-de-lacollection-camac.pdf, p. 7 [accessed on 13 April 2018].

56) The Royal College of Music in London now owns three books titled "Erard London Harp Ledgers" (hereinafter RCM 497), which contain important information about the manufacturing and sale of Erard harps made in London during the years ca. 1798-1915. It remains unclear why the same serial number appears in the archival records both in London and in Paris (according to the entry in the Parisian records, no. 3574 is a Gothic model, 46 strings, maple, made on 8 April 1910, sold in 1910 - Félix Lebano Buenos Aires). - Musée de la Musique, accessed from http://archivesmusee.citedelamusique.fr/pleyel/archives.html

57) Archival entry: "Mr Thomson / Bold Street, Liverpool / July 3 1824" - Erard London Harp Ledgers. MS 10111 Erard Ledger (2) [3565-3574], p. 220. - RCM 497.

58) E-mail from Roberta Scarzello dated 15. Feb. 2018; RENSCH 2007, op. cit. in footnote no. 19, fig. $10 \mathrm{~b}$.

59) Cf. http://www.deutsches-museum.de/de/forschung/forschungsbereiche/wissenschaftsgesch/sonicvisual-exhibit/early-pedal-harp/?sword_list[]=Poulopoulos\&no_cache=1 [accessed on 18 May 2018]. 
height $1720 \mathrm{~mm}$, number of strings 43 , string lengths 80 to $1530 \mathrm{~mm}$, originally 8 pedals, range $\mathrm{E}_{1}-\mathrm{e}^{4}$

Inscriptions: "MÉDAILLES D’OR lers. Prix / Dux Expositions de l Industrie Fr.se / de 1819 \& 1823.", “ERARD FRERES PAR BREVÊT D’INVENTION No. 993. / Facteurs de Forte Piano \& de Harpes du Roi. / de ses Menus Plaisirs De la Cour Impale de Russie. / de S. A. R. Mgr. le Due d’Orléans \& de sa Famille. / Rue du Mail Nos. 13 \& 21 à Paris.”

Origin: The harp was purchased in Paris from Erard ${ }^{60}$ in 1829 by the factory manager Johann Jakob Schwartz (1769-1848). ${ }^{61}$ The National Museum obtained it in 1961 from the collection of the Prague Conservatory. ${ }^{62}$ This could possibly be the harp donated to the Prague Conservatory in 1829 by its patron, Count František Josef of Vrtba (1759-1830).

Comparable specimen: Musée de la Musique Paris - Erard frères, single-action pedal harp No. 759, Paris 1821, 41 strings, 8 pedals (inv. no. E.984.3.1) ${ }^{63}$

\section{- Sébastien and Pierre Erard, double-action pedal harp No. 6147}

Gothic model, London, 1856 (inv. no. E 2003, acquisition no. 1916/58)

height $1775 \mathrm{~mm}$, number of strings 46, string lengths 115 to $1560 \mathrm{~mm}, 8$ pedals, range $C$ flat - f flat $^{4}$

Inscriptions: "Sebastian and Pierre Erards, Patent No. 6147 / 18 Great Marlborourgh Str. London". "6139 R. B." is printed on the bottom of the base, and there is a handwritten comment: "Ant [?] Germany".

Origin: The harp was purchased from the Erard London branch by Miss Fox in $1861 .{ }^{64}$ Later, the instrument belonged to the Czech harpist Karel Jirmus (1852-1928), then it was donated to the National Museum in 1870 by his father Václav Jirmus "before departing for America" 65

Comparable specimen: Victoria and Albert Museum - S. \& P. Erard, double-action pedal harp No. 6212, London, 1858, 46 strings, 8 pedals (inv. no. W.48-1931) ${ }^{66}$

60) The entry in the archives reads: "Grisse Satiné Grand model / 993 / ... Dez. 1825/ 5. Août 1829 / M. Joh. Jakob Schwartz à Vienne (Autriche)”. Erard Registres d’Atelier (Renseignés par Numéro de Série), accessed from http://archivesmusee.citedelamusique.fr/pleyel/archives.html [accessed on 10 Mar. 2018].

61)Cf.the entry "Schwarz(Schwartz) von Mohrenstern, JohannJakob(1769-1848)" - http://www.biographien. ac.at/oebl/oebL_S/Schwarz-Mohrenstern_Johann-Jakob_1769_1848.xml [accessed on 25 April 2018].

62) This may be a harp that was donated to the Prague Conservatory in 1829 by its patron, Count František Josef of Vrtba (1759-1830). Count F. Vrtba's gift is mentioned in J. Branberger. - BRANBERGER, Jan: Konservatoř hudby v Praze. Pamětní spis k stoletému jubileu založení ústavu (The Conservatory of Music in Prague, Commemoration of the $100^{\text {th }}$ Anniversary of the Institution's Founding), Knihtiskárna "Politiky", Prague 1911, p. 39; Acquisition Records for 1951-1965, p. 97 (ref. no. 1015/61).

63) Accessed from http://collectionsdumusee.philharmoniedeparis.fr/doc/MUSEE/0160878/harpe-asimple-mouvement\# [accessed on 23 April 2018].

64) The entry in the archival records reads: "6147 / N 1 / Maple Gothic / Oil Gold / April 1856. Sold $30^{\text {th }}$ January 1861 / to Miss Fox, of $N^{\circ} 111$ / Marine Parade, Brighton” Erard London Harp Ledgers, MS 10112 Erard Ledger 3 [6145-6154] p. 194. - RCM 497.

65) "Instruments" - Acquisition Records for 1948-1961, year 1958, p. 134; for more details, see ŠTĚDROŇ, Bohumír: Jirmus, Karel, in: Československý hudební slovník (Czechoslovak Musical Dictionary), vol. 1, Prague 1963, p. 613.

66) Accessed from http://collections.vam.ac.uk/item/O58933/pedal-harp-s-p-erard [accessed on 20 Feb. 2018]. 

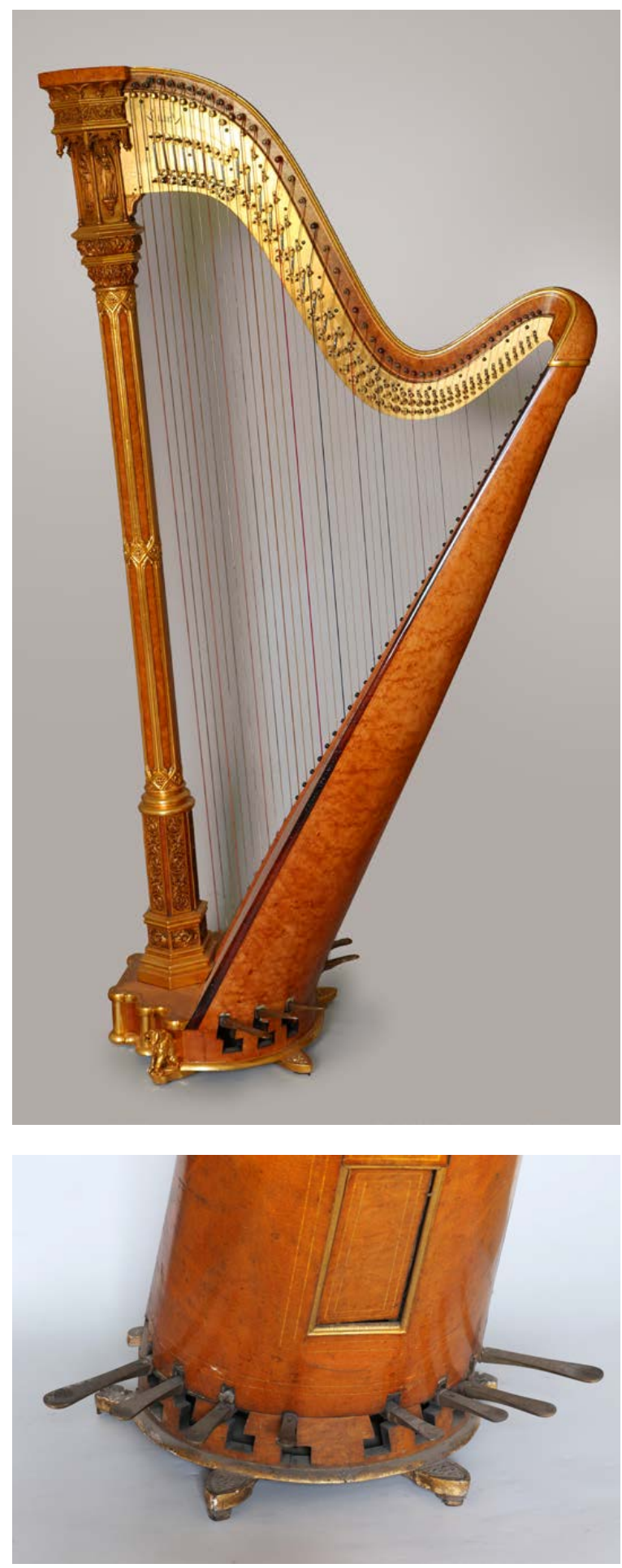

Harfa pedálová dvouzářezová, Erard No. 2284 / Double-action pedal harp, Erard No. 2284

Paříz / Paris, 1892

Celkový pohled, fotografie Jan Kříženecký / Full view, photograph by Jan Kř́ženecký NM-ČMH E 2425

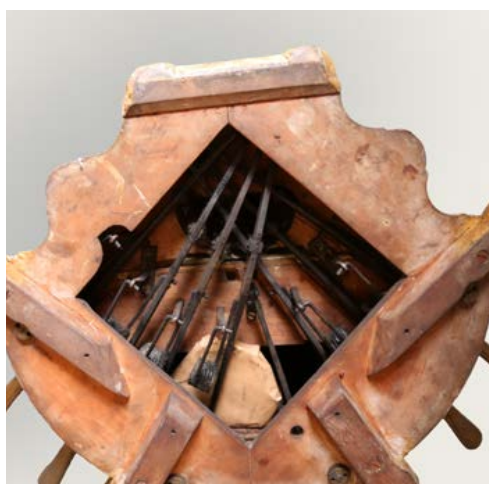

Harfa pedálová dvouzářezová / Double-action pedal harp, Sébastien and Pierre Erards No. 6147

Londýn / London, 1856

Zadní ćást podstavce - zářezy pro pedály vyřezány prímo do korpusu, fotografie Jan Kř́žženecký /

Rear of the pedal box - openings for the pedals cut directly into the body, photographs by Jan Kříženecký NM-ČMH E 2003 
- Erard, double-action pedal harp No. 2284

Gothic model, Paris, 1892 (inv. no. E 2425, acquisition no. 166/84)

height $1775 \mathrm{~mm}$, number of strings 46, string lengths 100 to $1570 \mathrm{~mm}$, number of pedals 7 , range $\mathrm{C}$ flat $_{1}-\mathrm{f} \mathrm{flat}^{4}$

Inscriptions: "Erard / PAR BREVET D’INVENTION ... 2284", "Erard / Facteur de Pianos et Harpes / 13 rue du Mail, Paris."

Origin: According to records in the books of the Erard company in Paris, the instrument was purchased in $1892^{67}$ by the Czech harpist, pianist, conductor, and composer Hanuš Trneček (1858-1914). ${ }^{68}$ In 1984 it was donated to the NM-ČMH by his pupil Václav Klička(1882-1953). ${ }^{69}$

Comparable specimen: Berliner Musikinstrumentenmuseum - Erard, double-action pedal harp No. 2247, Paris 1907, ${ }^{70}$ height 1770 mm, 46 strings, 7 pedals (inv. no. 4923) ${ }^{71}$

\section{Conclusion}

While, for example, the Vienna and Berlin collections each contain only one Erard harp, ${ }^{72}$ the National Museum - Czech Museum of Music has five of them from various time periods, making this collection of Erard harps one of the most important in central Europe.

A survey of the present state of research abroad by west-European experts on the given topic has revealed that Czech research in this direction is lagging behind. Although Erard harps and stringed keyboard instruments are found within the territory of the present-day Czech Republic that are not in the collection of the National Museum in Prague, there is a surprising lack of information in Czech about the manufacturer. New possibilities for Czech researchers have been opened up by on-line access to the Erard archives, which are exceptionally copious and well preserved in comparison with those of other musical instrument makers from the period in question. ${ }^{73}$

67) The entry in the archives reads: "Harpe Style Gothique a 46 cordes / 15 Mai 1892 / 31 Mai 1892 / Mr. Hans Trneček a Prague” - http://archivesmusee.citedelamusique.fr/pleyel/archives.html [accessed on 20 Feb. 2018].

68)Cf. ČERNUŠÁK, Gracian: Trneček, Hanuš, in: Československý hudební slovník osob a institucí(Czechoslovak Musical Dictionary of People and Institutions), vol. 2, Prague 1965, pp. 790-791.

69) Cf. ŠTĚDROŇ, Bohumír: Klička, Václav, in: Československý hudební slovník osob a institucí (Czechoslovak Musical Dictionary of People and Institutions), vol. 1, Prague 1963, pp. 671-672; Entry in the Acquisition Records: "L. and V. Klička / U Lužického semináře 10, Prague 1 (gift), 1984". - Acquisition Records 1984-1987, p. 13.

70) According to the archival ledgers in Paris, the making of the instrument was finished on 17 Nov. 1891. - Accessed from http://archivesmusee.citedelamusique.fr/pleyel/archives.html [accessed on 31 May 2018].

71) DROYSEN-REBER 1999, op. cit. in footnote no. 1, pp. 252-260.

72) The Sammlung alter Musikinstrumente at the Kunsthistorisches Museum Wien has an Erard doubleaction pedal harp (ca. 1811, inv. no. SAM 502). The Berliner Musikinstrumenten-Museum also has an Erard double-action pedal harp (Paris 1907, inv. no. 4923). There is a noteworthy collection at the Deutsches Museum München as well, which contains two Erard pedal harps - a Greek model No. 2631, London, 1818, inv. no. 16147 and a Gothic model, London, 1840.

73) An example would be tracing the "Czech footprints" in this documentation. The results of research would contribute towards, amongst other things, the study of the profile of Erard's customers from social and geographical perspectives. For the question of the economic mechanisms and strategies employed by Erard, see GUILLAUME-CASTEL 2017, op. cit. in footnote no. 26. 
The Erard harps in the NM- ̌́MH collection document the Czech socio-cultural context of the use of these instruments, built by the famed Parisian company. It was played in the milieu of intellectual society in Prague around the mid-nineteenth century, and at least one item in the collection was one of the instruments used for instruction at the Prague Conservatory. The latest Erard models were owned and used by important figures of the Czech performing arts from the end of the $19^{\text {th }}$ century through the first half of the twentieth (e.g. Hanuš Trneček, Karel Jirmus, Václav Klička, and Marie Zunová-Skalská).

Although Sébastien Erard was long regarded as the "inventor" of the double-action pedal harp, and he is still so regarded to some extent, organological research in recent years has confirmed that there were other harp makers who preceded him in working on the perfecting the structure and function of the pedal harp. Erard's work built upon the work of G. Cousineau and C. Groll, and Erard became the most successful producer of the double-action pedal harp with the fourchette (fork) mechanism (mécanique à fourchettes et à double mouvement). From about the middle of the nineteenth century, the shape of the concert harp and the lengths of its strings remain unchanged, while only the decorations of the instrument pass through all of the stylistic changes. ${ }^{74}$ Erard's "Gothic" model (e.g. harp No. 2284, inv. no. E 2425) was copied by several other manufacturers. Erard had imitators and competitors all over Europe; in Bohemia the Czech harp maker Alois Červenka (18581938) built upon Erard's work very successfully. Some reports in the period press from the late nineteenth century even expressed the opinion that Červenka's harps surpassed those of Erard in terms of the power of their sound and the purity of their tuning. ${ }^{75}$ It is in this context that one must reflect upon Erard's work as an instrument maker and emphasise its importance not only for the historical development of the harp, but also for his influence on the work of other manufacturers of musical instruments.

Address: Daniela Kotašová, České muzeum hudby,

Karmelitská 2, 11800 Praha 1, Czech Republic

E-mail: daniela_kotasova@nm.cz

74) WOLF, op. cit. in footnote no. 19, p. 4.

75) Pan Alois Červenka, Dalibor, vol. 12, 1890, no. 47, (13 Dec.), p. 374. For more details, especially about the main differences between the construction of the Erard and Červenka mechanisms, see KOTAŠOVÁ, Daniela: Alois Červenka a jeho harfy ve sbírce Českého muzea hudby (Alois Červenka and His Harps in the Collection of the Czech Museum of Music), Opus musicum, vol. 49, 2017, no. 3, pp. $16-17$. 


\section{Harfy značky Erard ve sbírce Českého muzea hudby}

\section{Daniela Kotašová}

\section{Úvod}

Současná sbírka harf NM-ČMH čítá celkem šedesát tři exemplářủ, ${ }^{1}$ přičemž nejpočetnější skupinu představuje soubor pedálových a háčkových harf. ${ }^{2}$ Kvantitativně nejvyšší zastoupení má tvorba francouzských výrobců, o necelou polovinu méně představuje česká produkce, která je počtem srovnatelná s výrobou rakouskou. ${ }^{3}$

Soubor obsahuje pět harf značky Erard, což představuje téměř $8 \% \mathrm{z}$ celkového počtu harfové sbírky. Početně srovnatelná kolekce je uložena např́klad v muzeu hudebních nástrojů v Bruselu, ${ }^{4}$ v bezprostředně nejbližším okolí Erardova působení. Pozoruhodné je, že pražský

Tento článek vznikl za finanční podpory Ministerstva kultury v rámci institucionálního financování dlouhodobého koncepčního rozvoje výzkumné organizace Národní muzeum (DKRVO 2018/39, 00023272).

Chtěla bych poděkovat všem, kdo přispěli svou radou, připomínkou nebo jinak cennou pomocí ke vzniku tohoto článku. Byli to Panagiotis Poulopoulos (Deutsches Museum München), Anne-Emmanuelle Ceulemans (Musée des Instruments de Musique de Bruxelles), Fanny Guillaume-Castel, Roberta Scarzello (Museo dell'Arpa Victor Salvi, Piasco), Rudolf Hopfner (Sammlung alter Musikinstrumente - Kunsthistorisches Museum Wien), Michael Mullen (Royal College of Music London), Lenka Stehnová (Městské muzeum Dvůr Králové nad Labem) a kolegyně i kolegové z Národního muzea - Českého muzea hudby (dále jen NM-ČMH). 1) Podrobnosti k historickému vývoji evropské harfy od renesance do počátku 20. stoletíviz DROYSEN-REBER, Dagmar: Europäische Harfen von der Renaissance bis in das frühe 20. Jahrhundert im Überblick, in: Harfen des Berliner Musikinstrumenten-Museums, Staatliches Institut für Musikforschung, Preußischer Kulturbesitz, Berlin 1999, s. 9-77 (dále DROYSEN-REBER 1999).

2) Srov. přehled všech typů harf ve sbírce NM-ČMH. KOTAŠOVÁ, Daniela: Háčkové harfy z pozůstalosti Marie Zunové-Skalské, Opus musicum, roč. 47, 2015, č. 5, s. 52.

3) Na kolekci čtyř pedálových harf jednozářezových vídeňského harfaře Franze Brunnera (1786-1840) bylo upozorněno v roce 2016. - KOTAŠOVÁ, Daniela: Harfy Franze Brunnera ve fondu Českého muzea hudby / Harps Made by Franz Brunner in the Collection of the Czech Museum of Music, Musicalia, roč. 8, 2016, č. 1-2, s. 78-85 (česká verze), s. 86-94 (anglická verze) (dále KOTAŠOVÁ 2016).

4) Dle písemného sdělení Fanny Guillaume-Castel z 16. 4.2018 spravuje Musée des Instruments de Musique $\checkmark$ Bruselu následující Erardovy harfy: jednozářezová bez sériového č., empirový model, Pařiž 1789, 40 strun, 8 pedálů (inv. č. JT005); dvouzářezová No. 2672, řecký model, Londýn 1819, 43 strun, 8 pedálů (inv. č. 3952); dvouzářezová No. 1883, gotický model, Paříž 1880, 47 strun, 8 pedálů (inv. č. 2487); dvouzářezová No. 3620, gotický model, Paříz 1910, 47 strun, 7 pedálů (inv. č. 3631); dvouzářezová No. 5983, gotický model, Londýn 80. léta 19. století, 46 strun, 8 pedálů (inv. č. 2008.014). Kromě toho muzeum spravuje pozoruhodnou kolekci šestnácti strunných klávesových nástrojů od Erarda. Další podrobnosti viz http://carmentis.kmkg-mrah.be [cit. 4. 5. 2018]. 
fond nespravuje žádný strunný klávesový nástroj tohoto výrobce, na rozdíl např́íklad od vídeňské či berlínské kolekce. ${ }^{5}$

\section{Pedálové harfy v NM-ČMH}

\begin{tabular}{|c|c|c|c|}
\hline Výrobce & Místo & Časové určení ${ }^{\prime}$ & Inv. č. \\
\hline J. R. Storck? & Paříž (?) & 80. - 90. léta 18. století & E 19977 \\
\hline Erard frères, No. 22 & Paříž & 1817 & E 88 \\
\hline H. P. Naderman, No. 162 & Pař́iž & 1818 & E 1995 \\
\hline H. (?) Naderman & Pař́iž & počátek 19. století & E 89 \\
\hline E. Challiot, No. 234 & Paříž & 1. polovina 19. století & E 2010 \\
\hline E. Challiot & Paříž & 1. polovina 19. století & E 2009 \\
\hline F. Brunner, No. 19 & Vídeň & 1. třetina 19. století & E 1999 \\
\hline F. Brunner, No. 31 & Vídeň & 1. třetina 19. století & E 2005 \\
\hline F. Brunner, No. 32 & Vídeň & 1. třetina 19. století & E 1532 \\
\hline F. Brunner, No. 49 & Vídeň & 1. třetina 19. století & E 1502 \\
\hline J. A. Stumpff & Londýn & 1. třetina 19. století & E 2008 \\
\hline S. Erard, No. 3574 & Londýn & 1824 & E 1994 \\
\hline Erard frères, No. 993 & Paříž & 1825 & E 2004 \\
\hline E. Klíčník & Praha & cca 1855-1857 & E 700 \\
\hline S. and P. Erard, No. 6147 & Londýn & 1856 & E 2003 \\
\hline Erard, No. 2284 & Paříž & 1892 & E 2425 \\
\hline anonym & $?$ & 19. století & E 1996 \\
\hline anonym & $?$ & 19. století & E 1998 \\
\hline A. Červenka & Praha & před 1895 (?) & E 2800 \\
\hline A. Červenka & Praha & kolem 1900 & E 2638 \\
\hline
\end{tabular}

Erardova harfa byla zjištěna v České republice v souboru Městského muzea ve Dvoře Králové nad Labem, kde je uložen řecký model jednozářezové pedálové harfy Erard frères No. 817 z roku 1822. ${ }^{8}$ Dva klavíry zn. Erard, které užíval Ludwig van Beethoven

5) Vídeňská sbírka obsahuje dva kladívkové klavíry: Paříz 1853 (inv. č. SAM 594); Paříz 1861 (inv. č. SAM 1200). - E-mail Rudolfa Hopfnera [15. 3. 2018]; Berlínské muzeum zahrnuje dvě cembala Erard: Paříž 1896, výr. č. 75899 (inv. č. 4924); Paříz 1889 (inv. č. 5191) a kladívkový klavír Erard, Londýn kolem 1850, výr. č. 2761 (inv. č. 4564). - DROYSEN-REBER, Dagmar - RESTLE, Konstantin: Berliner Musikinstrumenten-Museum, Bestandkatalog der europäischen Musikinstrumente 1888-1993, Staatliches Institut für Musikforschung, Preußischer Kulturbesitz, Berlin 1993, s. 356, 358, 408.

6) Řazení nástrojů je uvedeno chronologicky, u ostatních pedálových harf se v dataci čerpalo z publikací, viz ČÍŽEK, Bohuslav: Hudební nástroje evropské hudební kultury, Aventinum, Praha 2002, s. 42-43 (dále ČÍŽEK 2002); MÜLLER, Miloš: Jan Křtitel Krumpholtz, Národní knihovna, Praha 1999, s. 133-135 (dále MÜLLER).

7) Podrobnosti k harfě s inv. č. E 1997 viz KOTAŠOVÁ, Daniela: Die Pedalharfe eines unbekannten Instrumentenbauers aus der Sammlung von Marie Zunová-Skalská, Phoibos - Zeitschrift für Zupfmusik https:// openjournals.uni-bayreuth.de/index.php/phoibos (v tisku).

8) Nápis na harfě: „Érard Fréres. par brevet d’invention No 817. / Facteurs de Forte Piano \& de Harp du Roi / desés Menue Plaisir Dela Cour Imperiale de Russie. / de S. A. S. Monseigneurte Duc d’Orléans et desa famille Rue du Mail Nos 13 \& 21 à Paris." 
na počátku 19. století, má ve správě jako významnou kulturní památku Státní zámek Hradec nad Moravicí. 9

\section{Současný stav bádání}

Jedny z prvních česky psaných statí o Erardovi byly publikovány v roce 1894 v Ottově slovníku naučném ${ }^{10}$ a v Pazdírkově hudebním slovníku naučném. ${ }^{11}$ Další české texty o tomto výrobci jsou koncipovány pouze všeobecně nebo útržkovitě. ${ }^{12}$ Teprve až Bohuslav Čížek věnuje Erardovi relativně větší pozornost, poprvé v rámci všeobecného pojednání o hudebních nástrojích ze sbírky NM-ČMH i dalších institucí, ${ }^{13}$ podrobnější biografické údaje napsal v kontextu historických klavírů v Čechách a na Moravě. ${ }^{14}$ Další české práce pojednávající o Erardovi a jeho díle nebyly zjištěny. Naproti tomu někteří čeští odborníci s oblibou zdůrazňují, že na dílčích konstrukčních návrzích a změnách u harfy se ještě před Erardem podílel osobně Jan Křtitel Krumpholtz (1747-1790). ${ }^{15}$

Kompetentní údaje o nástrojařské rodině Erardů přináší cizojazyčná odborná literatura. Kromě fundovaných hesel v lexikografické produkci s odkazem na další práce ${ }^{16}$ vzniklo v posledních desetiletích několik důležitých pojednání. ${ }^{17} \mathrm{O}$ výsledcích studia v nedávno objevených archivech firmy Erard informuje publikace autorského týmu v čele s francouzským muzikologem, organologem, pedagogem a kurátorem Robertem Adelsonem, přičemž první část se týká vynálezů, obchodů, korespondence se skladateli a umělci, díl druhý se vztahuje

9) Stolový klavír Erard fréres No. 37, Paříž 1803? (inv. č. HM 00614); klavírní křídlo Erard fréres, No. 143, Paříz 1803 (inv. č. HM 00613). Podrobnosti viz ČÍŽEK, Bohuslav: Historické klavíry v Čechách a na Moravě, Togga, Praha 2010, s. 72-74 (dále ČÍŽEK 2010).

10) Ottův slovník naučný. Ilustrovaná encyklopedie obecných vědomostí. 8. díl, J. Otto, Praha 1894, s. 690. Dostupné z http://www.pdfknihy.maxzone.eu/books/OSN/otto08.pdf [cit. 21. 5. 2018].

11) Pazdírkův hudebni slovník naučný II., část osobní, 1. sv., Ol. Pazdírek, Brno 1937, s. 238.

12) ZUNOVÁ, Marie: $O$ harfě, Oldřich Blecha, Plzeň 1926, s. 3; HUTTER, Josef: Hudební nástroje, František Novák, Praha 1945, s. 129-130; MÜLLER, op. cit. v pozn. 6, s. 118-119; Významný český organolog Pavel Kurfürst krátce zmiňuje Sébastiena Erarda v souvislosti s „klávesovými chordofony“ viz KURFÜRST, Pavel: Hudební nástroje, Togga, Praha 2002, s. 636, 638, 639.

13) ČÍŽEK 2002, op. cit. v pozn. 6, s. 43-44.

14) Škoda, že koncepce knihy nedovolila uvedení zdrojů, z nichž autor čerpal údaje. - ČÍžEKEK 2010, op. cit. v pozn. 9, s. 72.

15) Např. MÜLLER, op. cit. v pozn. 6, s. 118.

16) GÉTREAU, Florence: Erard, in: Die Musik in Geschichte und Gegenwart, Personalteil 6, ed. L. Finscher, Stuttgart 2001, 2. vyd., s. 391-396 (dále GÉTREAU); GRIFFITHS, Ann - MACNUTT, Richard: Erard, in: The New Grove Dictionary of Music and Musicians. 2. Edition, Vol. 8, ed. S. Sadie, Macmillan Publishers Limited 2002, New York, 2002, s. 276-279 (dále GRIFFITHS - MACNUTT).

17) Např. FRICK, Rudolf: 1794-1994. Bemerkungen zum Stand der Erard-Forschung, in: Sébastien Erard: Ein europäischer Pionier des Instrumentenbaus. Internationales Erard-Symposium, Michaelsteiner Konferenzberichte, Bd. 48, Michaelstein 1994; FRICK, Rudolf: Die schweizerischen Ursprünge der Familie Erard, in: Sébastien Erard: Ein europäischer Pionier des Instrumentenbaus. Internationales Erard-Symposium, Michaelsteiner Konferenzberichte, Bd. 48, Michaelstein 1994, s. 15-18 (dále FRICK); ADELSON, Robert BARTHEK, Laure - FOUSSARD, Michel et al.: Erard and the Invention of the Modern Harp, 1811-2011, Musée du Palais Lascaris, Nice 2011. 
k rodinné korespondenci. ${ }^{18}$ Většina uvedených titulů je v České republice bohužel velmi obtížně dostupná.

Zahraniční specialisté nahližejí na tuto problematiku nejen z organologického hlediska, ${ }^{19}$ ale také pohledem dalších souvisejících oborů a disciplín. V současné době vstupuje do finále víceletý projekt vědeckých pracovníkủ v Mnichově, ${ }^{20}$ mezi jehož nejnovější výstupy náleží prezentace interdisciplinárního výzkumu na poli konzervace a restaurování Erardovy harfy, No. 2631, sbírkového předmětu z Deutsches Museum München. Experti provedli zvukovou analýzu Erardovy harfy, ${ }^{21}$ probíhá diskuze ve věci priorit výzkumu „nehmotných hodnot“ (např́klad zvuku) za cenu rizika ztráty „hmatatelných hodnot“ (např. materiálu) ${ }^{22}$ apod.

Téma Erardovy harfy se v posledních letech stalo předmětem zájmu studentských prací na několika zahraničních univerzitách. ${ }^{23}$ Jeden z prvních pokusů o uchopení otázky výroby hudebních nástrojů jako celku ze sociálně-ekonomického hlediska byl obhájen na londýnské univerzitě, přičemž se doktorandka zaměřila na výzkum hudebních nástrojů jako řemeslného průmyslu v Londýně mezi lety $1760-1820 .{ }^{24}$ Výskyt pedálové harfy v koloniální Austrálii

18) ADELSON, Robert - ROUDIER, Alain - NEX, Jenny - BARTHEL, Laure: History of the Erard Piano and Harp in Letters and Documents, 1785-1959, Cambridge University Press, Cambridge 2015.

19) Napr. RENSCH, Roslyn: The late eighteenth and early nineteenth centuries - Erard. Harps and Harpists, Bloomington, Indiana University Press, 2. vydání 2007, s. 147-150 (dále RENSCH); PARKER, Mike: The Eighth Pedal, Fact or Fiction?, 2008, dostupné z http://www.harpspectrum.org/historical/the_eighth_pedal. shtml [cit. 27. 2. 2018]; WOLF, Beat: „Vom Kniff zum Tritt". Die Chromatisierung der Harfe, Schaffhausen 2009, s. 3-4, dostupné z http://www.beatwolf.ch/Portals/14/pdf/knifftritt_2009.pdf [cit. 22. 3. 2018] (dále WOLF); BALDWIN, Mike: The Inventor of the Double-Action Pedal Harp with Fourchettes: Erard versus Groll, London 2009, dostupné z www.harpspectrum.org/historical/Erard\%20versus\%20Groll.shtml [cit. 25. 1. 2018].

20) Projekt řeši vývoj rané fáze pedálové harfy (1780-1830) z perspektivy muzikologické, historické, technické i sociálně kulturní. - POULOPOULOS, Panagiotis: A Creative Triangle of Mechanics, Acoustics and Aesthetics: The Early Pedal Harp (1780-1830) as a Symbol of Innovative Transformation. Teze viz https://portal.volkswagenstiftung.de/search/projectPDF.do?projectId=7314 [cit. 10. 4. 2018]; RICHTER, Luise: Untersuchung der Dekoration einer Erard-Doppelpedalharfe, viz http://www.deutsches-museum.de/forschung/forschungsbereiche/sammlungen/restaurierungsforsch/pedalharfe/ [cit. 10. 4. 2018].

21) POULOPOULOS, Panagiotis - PAMPLONA, Marisa - RICHTER, Luise - PLATH, Niko: Conservation Issues on Historical Pedal Harps: Preserving Tangible and Intangible Properties, in: Preservation of Wooden Musical Instruments: Ethics, Practice and Assessment. Proceedings of $4^{\text {th }}$ Annual Conference of the COST Action FP1302 WoodMusICK. Brussels, ed. P. Vandervellen, Muziekinstrumentenmuseum, 2017, s. 69-72, viz http://woodmusick.org/wp-content/uploads/Proceedings_WoodMusICK_BRS.pdf [cit. 23. 3. 2018] (dále POULOPOULOS 2017).

22) DE BRUYN, Vera: „Material or sound?" - Risk-benefit Analysis in the Recording of Musical Instruments (nepublikovaný článek prezentovaný v Ringve Music Museum v norském Trondheimu, během konference CIMCIM The Nordic Countries, 24. - 31. srpna 2014). Srov. POULOPOULOS 2017, op. cit. v pozn. 21, s. 71-72.

23) Např. BÜHL, Franciska: Untersuchung einer Erard-Doppelpedalharfe von 1820-1825, bakalářská práce, Technische Universität München (Studiengang Restaurierung, Kunsttechnologie und Konservierungswissenschaft), Mnichov 2014. Dostupné z https://www.rkk.ar.tum.de/fileadmin/w0Oble/ www/media_rkk/downloads/Diplom-_und_BA-Arbeiten/BuehL_2013_BA-Thesis_online.pdf [cit. 20. 2. 2018] (dále BÜHL); WALTER, Sandra: Die Einfachpedalharfe No. 512 der Brüder Erard aus dem Couven-Museum Aachen, Untersuchungen zu Bestand, Zustand, historischer Kontextualisierung sowie Durchführung der Konservierung, Restaurierung und Neubesaitung, diplomová práce, Fachhochschule Erfurt 2010. Teze na https://www.fh-erfurt.de/kr/fileadmin/KR/Abschlussarbeiten/2010/Walter.pdf [cit. 21. 3. 2018].

24) NEX, Jennifer Susan: The Business of Musical-Instrument Making in Early Industrial London, Goldsmiths College, University of London 2013. Dostupné z https://research.gold. 
v období let 1830-1866 byl zmapován na univerzitě v Adelaide. ${ }^{25}$ Dosud neprozkoumané téma spolupráce Erardovy pařížské a londýnské pobočky v letech 1790-1810 při výrobě a prodeji pedálové harfy jednozářezové se stalo těžištěm magisterské práce v roce 2017 na pařížské Sorbonně. ${ }^{26}$

\section{Dějiny firmy Erard a její podíl na vývoji harfy}

Sébastien Erard ${ }^{27}$ (5. 4. 1752 Strasbourg - Passy 5. 8. 1831) se narodil jako čtvrté dítě truhláře Louise-Antoina Erarda (1685-1758) ${ }^{28}$ a jeho druhé ženy Barbe Meyer. V šesti letech Sébastienovi zemřel otec, patrně i proto nelze doložit jeho vzdělání. Lze předpokládat, že byl vychován v komunitě zkušených řemeslníků - strýců, bratranců i kmotra, kteří působili jako umělečtí truhláři a zlatníci, zejména v církevním prostředí. Je možné, že Sébastienovi bratř̀ mohli být v kontaktu také s dílnou Gottfrieda Silbermanna ve Strasbourgu a seznámili se s dílem mladších členů slavné varhanářské dynastie. ${ }^{29}$

Kolem roku 1768 odešel do Paříže a nastoupil do služeb vévodkyně de Villeroy (17311816), která mu poskytla prostory pro dílnu na svém panském sídle v Rue de Bourbon. ${ }^{30} \mathrm{Na}$ Sébastienovu žádost přichází do Pařiže roku 1781 jeho starší bratr Jean-Baptiste (17491826). ${ }^{31}$ Dne 5. února 1785 dostává Sébastien od Ludvíka XVI. licenci na stavbu hudebních nástrojů, ačkoliv nepatřil k cechu pařížských výrobců.

Bratři Erardové založili 1. ledna roku 1788 obchodní společnost, která od té doby začala působit pod názvem Erard frères. ${ }^{32}$ Finanční vedení převzal Sébastien. V Londýně na „18 Great Marlborough Street“ založil roku 1792 filiální podnik, přičemž se v Anglii soustředil zejména na výrobu harf, které byly do té doby téměř všechny dováženy z Francie. V roce 1795 se vrátil Sébastian zpátky do Paříže, ale nadále se pohyboval mezi oběma místy, kde prezentoval výsledky nástrojařských zlepšení a vynálezů. Patenty získal jak v Anglii (16. 6. 1801,

ac.uk/9606/1/MUS_thesis_Nex_2013.pdf [cit. 19. 2. 2018] (dále NEX 2013).

25) HALLO, Rosemary Margaret: Erard, Bochsa and their impact on harp music-making in Australia (1830-1866): an early history from documents. University of Adelaide, Elder Conservatorium of Music, 2014. Teze viz https:// digital.library.adelaide.edu.au/dspace/handle/2440/86482 [cit. 19. 2. 2018].

26) GUILLAUME-CASTEL, Fanny: L'entreprise Erard: étude d'une entreprise basée à Paris et à Londres entre les années 1790 et 1810 à travers la fabrication et la vente des harpes, Université Paris 1 Panthéon-Sorbonne, History Department, Pař́řz červen 2017. Informace z emailové korespondence s Fanny Guillaume-Castel ze dne 18. 4. 2018 (dále GUILLAUME-CASTEL 2017).

27) Zápis přijmení „Erard“ se v archivní dokumentaci vyskytuje také v podobě „Erhard“.

28) Stopa Sébastienovy rodiny sahá na dnešní území Švýcarska, kde jeho děd Hubert zemřel v Bassecourtu u Delémontu (diecéze Basilej) roku 1722. - BÜHL 2014, op. cit. v pozn. 23, s. 20. FRICK, op. cit. v pozn. 17, s. 16.

29) GRIFFITHS - MACNUTT, op. cit. v pozn. 16, s. 276.

30) Na jiném místě Erard zkonstruoval svůj nejstarší dochovaný nástroj, v roce 1779 označený jako „clavecin mécanique“. Dnes je exemplář uložen v pařižské sbírce Musée de la Musique. - GÉTREAU, op. cit. v pozn. 16, s. 391.

31) Literatura uvádí různá data narození Jeana-Baptisty: rok 1745 (DROYSEN-REBER 1999, op. cit. v pozn. 1, s. 299); rok 1750 - NOVAK CLINKSALE, Martha: Makers of the Piano: 1820-1860, 2. díl, Oxford University Press, New York 1999, s. 118 (dále NOVAK); rok 1749 (GÉTREAU, op. cit. v pozn. 16, s. 391).

32) Pařížská pobočka společnosti bratrů Erardů byla ukončena smrtí Jeana-Baptisty dne 9. dubna 1826. Poté vedl Sébastien podnik sám až do své smrti. 
dále 1808), tak ve Francii $(1802,1806)$ a po víceletém úsilí obdržel 2. listopadu 1810 patent na dvouzářezovou pedálovou harfu s vidličkovou mechanikou (londýnský patent No. 3332).

V době Prvního Francouzského císařství (Empire Français, 1804-1815) byli bratři jmenováni dvorními dodavateli císaře a krále Napoleona Bonaparta. Roku 1819 se konala první výstava s obdržením zlaté medaile za čtyři klavíry a dvě harfy. V roce 1820 Erard zakoupil privátní sídlo - zámek La Muette v Passy u Pařižě. ${ }^{33}$ Erard byl také považován za mistra v opravě varhan.

Pierre Orphée Erard $^{34}$ (10. 3. 1794 - 16. 8. 1855), syn Jean-Baptisty Erarda, synovec Sébastiena, získal vzdělání v hudbě i v angličtině. Vedení londýnské pobočky převzal 17. května 1814 a řídil ho až do roku 1829. Na rozvoji stavby klavíru a harfy se podílel sám i společně se svým strýcem Sébastienem, po jehož smrti se stal jediným dědicem podniku v Paříži i v Londýně.

V roce 1834 se Pierre Erard vrátil do Pařiže a oženil se sestřenicí Camille Février (1813-1889), na niž po jeho smrti v roce 1855 přešel podnik. Madam Erard svěřila londýnskou pobočku M. Bruzaudovi, řízení pařížské firmy přenechala svému švagrovi Antoinu Eugènovi Schaefferovi (1802-1873). Dne 25. srpna 1873 uzavřela Camille Erard obchodní smlouvu s Amédée Blondel a vedla ji dále pod jménem Erard et C $C^{\text {ie }}$ (1873-1889). Po smrti Camille Erard podnik zdědila její neteř a zároveň adoptivní dcera, madam de Franqueville. Erardova továrna v Londýně byla prodána v aukci dne 9. září 1890 a velkou část podniku získal J. George Morley. ${ }^{35}$ Londýnská pobočka zažila do roku 1930 postupný úpadek. Blondel vedl pařížskou fabriku do roku 1935 pod firemním názvem Blondel E C $C^{i e}$ (Maison Erard). Společnost existovala pod jménem Guichard $\mathcal{E} C^{i e}$ (Maison Erard) až do roku 1959, ve kterém se sloučila s domem Gaveau. V květnu 1962 byla také připojena firma Pleyel. Tyto tři společnosti koupil Schimmel v roce $1970 .^{36}$

\section{Analýza harf zn. Erard ve sbírce NM-ČMH}

Na konci 18. století dospělo více harfařů ke zjištění, že hudební potenciál jednozářezové pedálové harfy je limitován, zejména ve srovnání se strunnými klávesovými nástroji (např. cembalo, klavír). Sébastien Erard obdržel v říjnu 1794 v Londýně svůj první patent na harfu $\mathrm{s}$ vidličkovým mechanismem na otáčivých terčících (fourchettes). Umožnil realizaci pedálů s dvojím zářezem - každý ze sedmi pedálů lze sešlápnout do dvou pozic (zářezů). ${ }^{37}$ Tímto způsobem lze zvyšovat všechny stejnojmenné tóny ve všech oktávách o dva půltóny, což

33) V inventáři Château de la Muette v Passy se dochovalo přibližně 260 obrazů mimořádné hodnoty. Je pozoruhodné, že na zámku nebyl objeven žádný hudební nástroj. Podrobnosti viz GRIFFITHS, Ann: Sébastien Erard. A Dynasty of Harpmakers, World Harp Congress Review, 2002. Dostupné z http://www.adlaismusicpublishers. co.uk/pages/harpists/erard.htm [cit. 14. 3. 2018] (dále GRIFFITHS 2002).

34) Přesné jméno Jean-Baptiste Orphée Pierre Erard. Srov. NOVAK, op. cit. v pozn. 31, s. 118.

35) GRIFFITHS - MACNUTT, op. cit. v pozn. 16, s. 278.

36) GÉTREAU, op. cit. v pozn. 16, s. 394.

37) Struna se pohybem při sešlápnutí pedálu více napne, zároveň se zkrátí a zvýší se její ladění o půltón (jeden zářez) anebo o celý tón (dva zářezy). Napríklad sešlápnutím pedálu o jeden zářez se fes změní na fa dále $\mathrm{k}$ fis. 
u jednozářezové pedálové harfy možné nebylo. Základní ladění dvouzářezové pedálové harfy je Ces dur.

První nástrojař, který experimentoval s typem dvouzářezové harfy (1781), byl Georges Cousineau (1733-1800). ${ }^{38}$ Roku 1782 postavil nástroj se čtrnácti pedály, s berličkovou mechanikou (mécanique à béquilles), ale jeho vynález dvouzářezové pedálové harfy zůstal stranou pozornosti. Charles Groll (také Gröll, 1770-1857) nahlásil v Londýně již roku 1807 patent na dvouzářezovou pedálovou harfu, který Erard od něj zřejmě musel odkoupit. ${ }^{39}$ Teprve až Erardovi se podařilo prosadit vynález, patentovaný roku $1810 .{ }^{40}$ Ačkoli Erard tento druh harfy nevynalezl, vyhrál „závod“ komerčně. Toto řešení se uplatňuje prakticky až dodnes, $\mathrm{s}$ příslušným zdokonalením konstrukce moderních koncertních harf, při nichž se např́klad využívají takové materiály, jako je např. uhlíkové vlákno nebo teflon. ${ }^{41}$

Tři nástroje z pětice Erardových harf ze sbírky NM-ČMH jsou dodnes opatřeny původní konstrukcí s osmým pedálem. Erard je konstruoval zhruba do poloviny 19. století. Pedál, umístěný jako čtvrtý zleva, otvíral a zavíral pět prahových záklopek opatřených žaluziemi na zadní straně korpusu. Účelem bylo docílit různých zvukových efektů (crescendo, decrescendo, tremolo apod.). ${ }^{42}$ Nové výsledky ze současného výzkumu ukazují, že Erardův zákazník měl před nákupem patrně možnost výběru, zda si objedná harfu se systémem osmého pedálu, anebo bez něj. ${ }^{43}$

Dekorace harfy začala kolem roku 1800 nabývat na stále větším významu, zejména jako prezentace módního nástroje, který byl žádán ve vyšších společenských vrstvách. Erardovo zdobení se vyznačuje prvky palmetových či zoomorfních motivů (např. plastických hlav beranů nebo tvarů koní). Srovnáme-li vypracování hlavice s motivy beraní hlavy harfy No. 22 (inv. č. E 88) zejména s jinými nástroji tohoto období, je zřejmé, že stejné zdobení Erard uplatnil u starších modelů nástrojů jednozářezových na rozdíl od naší harfy dvouzářezové. Vzhledem k tomu, že mechanismus dvojitého zářezu byl patentován roku 1810, lze předpokládat, že náš exemplář z roku 1817 patřil k prvním harfám s novým typem konstrukce dvojího zářezu s dekoračními prvky starších modelů s jedním zářezem. ${ }^{44} \mathrm{~V}$ následujícím období se stala komerčně nejúspěšnější tzv. gotická harfa, v jejímž novém designu se Erard inspiroval prvky módního neogotického stylu.

38) ZINGEL, Hans Joachim: Lexikon der Harfe, Laaber-Verlag, Regensburg 1977, s. 44.

39) WOLF, op. cit. v pozn. 19, s. 3.

40) Erard prodal první exemplář dvouzářezové pedálové harfy No. 1387 na londýnské Great Marlborough Street dne 11. prosince 1811. Nástroj stále existuje v soukromé sbírce v Anglii, má 43 strun, rozsah $\mathrm{Es}_{2}-\mathrm{es}^{3}$. GRIFFITHS 2002, op. cit. v pozn. 33.

41) WOLF, op. cit. v pozn. 19, s. 4.

42) Podrobnosti k osmému pedálu viz KOTAŠOVÁ 2016, op. cit. v pozn. 3, s. 81-82.

43) Emailová konzultace s Fanny Guillaume-Castel ze dne 20. 4. 2018.

44) Jeden z prvních řeckých modelů, konstruovaný již s dvojím zářezem, představuje např. harfa o čtyři roky starší než náš exemplář, tedy z roku 1821. Vznikla v Londýně, má No. 3070, 43 strun, 7 pedálů (inv. č. E. 0997, Musée de la Musique, Paříž). Dostupné z http://collectionsdumusee.philharmoniedeparis.fr/doc/ MUSEE/0162312/harpe-a-double-mouvement [cit. 23. 4. 2018]. 
Pierre Erard usiloval o zvukově silnější a odolnější stavbu harfy, než byly předchozí modely. Ve své (reklamní) knize roku $1821^{45}$ mimo jiné napsal, že Erardové kompletně obnovují stavbu korpusu, které přičítá konstrukční nedostatky. ${ }^{46}$ Rezonanční desku dvouzářezové pedálové harfy prodloužil o cca 4-10 cm, aby na ní mohlo být umístěno čtyřicet šest strun (srov. harfa No. 6147, inv. č. E 2003). Spodní část korpusu zesílil natolik, že byla zhruba dvojnásobná, než je jeho obvyklá síla. Zářezy pro pedály byly vypracovány přímo do zadní stěny korpusu (srov. podstavec harfy No. 2284, inv. č. E 2425). Londýnský patent č. 6962 obdržel Pierre Erard dne 18. prosince 1835. Další konstrukční změny k tomuto typu harfy už nejsou známy.

Anglický gotický model harfy No. 6147 (inv. č. E 2003) z roku 1856 se vyznačuje následujícími prvky:

- hlavice je zdobena plastikami ženských postav - karyatid a andělů hrajících na historické hudební nástroje

- hexagonální půdorys sloupu s hlavicí

- žaluziový mechanismus s osmým pedálem

Tento typ harfy se odlišuje jen v malých rozdílech, včetně dekorace, od cca půlstoletí mladšího francouzského modelu, jehož názorný př́iklad reprezentuje gotická harfa No. 2284 (inv. č. E 2425). Pařižský nástroj je konstruován již bez žaluziového mechanismu, pedálové jazyky na zadní části podstavce jsou tvarově mírné ohnuté, obě přední nohy podstavce jsou vyřezány ve tvaru lva odlitého z masivní mosazi, kovová deska na krku je zapuštěna př́mo do ramene apod. Uvedený model se zhotovoval v Paříži v sériích ještě ve 20. století. ${ }^{47}$

Z kolekce Erardových harf v NM-ČMH prošla největším zásahem harfa No. 3574 (inv. č. 1994). Původně řecký model harfy, postavený v Anglii 1824, zrestauroval na přelomu 19. a 20. století Joseph George Morley (1847-1922). ${ }^{48}$ Kromě toho vyměnil sloup i hlavici, pravděpodobně přestavěl i původní žaluziový mechanismus na harfu se sedmi pedály.

Některé Erardovy harfy mají kromě standardních nápisů na bočních stranách krku také záznamy na dalších částech nástroje. Vyskytují se v podobě čísla, které se objevuje nejčastěji, nápisu, iniciály, razítka nebo ručního zápisu. Většinou se nacházejí pod krkem, na podstavci, pedálech apod. Příklad tvoří harfa se sériovým číslem 6147 (inv. č. E 2003), která má na spodní části podstavce vyražený číselný údaj 6139 s písmeny $R$. B. a rukopisný záznam Ant [?] Germany. Dosud však nebyla potvrzena žádná specifická korelace nebo vzorec mezi

45) ERARD, Pierre: The Harp: In its present improved State Compared with The Original Pedal Harp, Erard, London 1821.

46) Stavba korpusu ale žádné konstrukční nedokonalosti nevykazovala. Wolf upozorňuje, že toto mylné hodnocení stále prètrvává, dokonce i v aktuálních odborných publikacích. - WOLF, op. cit. v pozn. 19, s. 3.

47) DROYSEN-REBER 1999, op. cit. v pozn. 1, s. 256.

48) Joseph George Morley, syn George Morleye (1790-1852), který v roce 1818 v Londýně zaregistroval svou firmu na výrobu, ladění a opravy harfy. Joseph George v roce 1890 převzal sklady a dobré jméno společnosti Erard $v$ Londýně a založil obchod a dílny. Až do konce 1. světové války byl nejvýznamnějším výrobcem harfy v Británii. Postavil nástroj se čtyřiceti osmi strunami inzerovanou jako „Largest Pedal Harp in the World“. Po válce klesla poptávka po harfách a firma se soustředila na opravy a výrobu malých irských harf. - Srov. ACKER, Anne Beetem: Morley, Robert, e Co. Dostupné z http://www.oxfordmusiconline.com/grovemusic [cit. 8. 5. 2018]; RENSCH, op. cit. v pozn. 19, s. 179. 
dvěma čísly na různých dílech harfy. „Skryté“ číselné údaje na kovových a dřevěných částech jsou vyšší nebo nižší, než je „oficiální “ číslo vyryté na mosazné desce krku. Uvedené nápisy s největší pravděpodobností dokumentují dělbu práce při výrobě harfy v manufakturách, pracovníci si zřejmě číselně značili dřevěné části kvưli snadnějšímu finálnímu sestavování různých dílů nástroje podle konkrétního modelu. ${ }^{49}$

\section{Popis harf50}

- Erard frères, pedálová harfa dvouzářezová No. 22

řecký model, Paříž, 1817 (inv. č. E 88, př. č. 1105/51)

výška 1710 mm, počet strun 43, menzury ${ }^{51} 90$ a 1470 mm, 8 pedálů, rozsah $E_{1}-e^{4}$

Nápisy: „Par Brevet d’invention No. 22. / ERARD FRÈRES / Facteur de Forté Piano \& de Harpes du Roi / de Les Menus Plaisirs, \& de la Cour Impériale de Russie / Rue du Mail, Nos 13 \& 21, à Paris."

Původ: Harfa byla zakoupena v srpnu 1817 pro Alberta hraběte Gyulay von Máros-Németh und Nádaska (1766-1835), ${ }^{52}$ polního maršálaporučíka mad'arské národnosti. ${ }^{53} \mathrm{~V}$ dalších záznamech je uvedeno, že na nástroj hrála manželka Františka Palackého Terezie, roz. Měchurová (1807-1860), a její sestra Antonie (1810-1836). Do Národního muzea harfu daroval roku 1898 František Ladislav Rieger (1818-1903), zet českého historika Františka Palackého. ${ }^{54}$

Srovnatelný exemplář: Collection Camac Ancenis - Erard Fréres, dvouzářezová harfa No. 901, empirový model, Paříž 1824, 43 strun, 8 pedálü55

\section{- Sébastien Erard, pedálová harfa dvouzářezová No. 3574}

řecký model, Londýn, 1824 (inv. č. E 1994, př. č. 14/64)

výška $1704 \mathrm{~mm}$, počet strun 43, menzury 112 a $1470 \mathrm{~mm}$, dnes 7 pedálů, rozsah $\mathrm{E}_{1}-\mathrm{e}^{4}$

Nápisy: „Sebastian Erard's / Patent Nr. 3574 / 18. Great Marlborough Street London“, „MAKER / By Special Appointment / to his Majesty and the / ROYAL FAMILY." „Restored by J. George Morley, Harp Maker from Erard's / C. Sussex Place, South Kensington, London"

49) Výzkumem v tomto směru se aktuálně zabývá P. Poulopoulos.

50) Podrobný organologický popis ke každé Erardově harfě ze sbírky NM-ČMH, včetně fotodokumentace, je uložen v systematické evidenci v oddělení hudebních nástrojů NM-ČMH. Předložený popis obsahuje jeho zkrácenou podobu.

51) Vibrační délka nejkratší a nejdelší struny.

52) Podrobnosti na http://www.napoleon-online.de/AU_Generale/html/gyulay.html [cit. 24. 4. 2018].

53) $V$ archivním zápisu stojí: „rouge au lacqu[e] [červená lakovaná] au Baron Bottmowiesky [?] pour le C[ompte?] Albert Giulay a Pest Hongri 22. 8. 1817". - Erard Registres d’Atelier (Renseignés par Numéro de Série), dostupné z http://archivesmusee.citedelamusique.fr/pleyel/archives.html [cit. 9. 2. 2018].

54) F. L. Rieger daroval Museu Království českého roku 1898 dvě harfy, kromě výše uvedené také jednozářezovou pedálovou harfu od Nadermana (inv. č. E 89). - Historické muzeum NM, oddělení starších českých dějin, systematická evidence sbírky - Úbytky.

55) Soukromá sbírka Camac. La harpe de Marie-Antoinette à nos jours, Château d'Ancenis A partir du ler Jullet 2017. Dostupné z https://www.camac-harps.com/wp-content/uploads/2017/06/tresors-de-la-collection-camac.pdf, s. 7 [cit. 13. 4. 2018]. 
Harfy značky Erard ve sbírce Českého muzea hudby
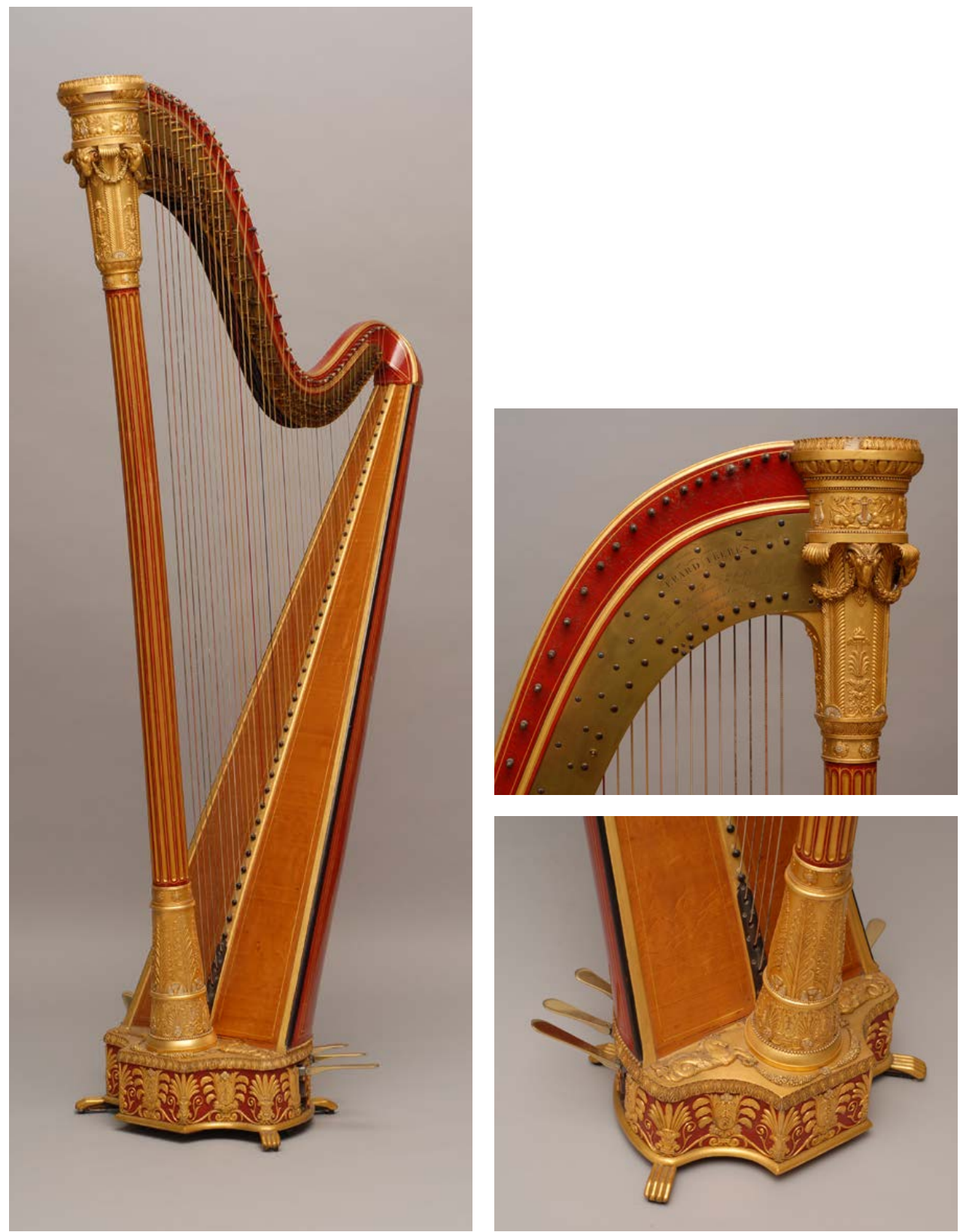

Harfa pedálová dvouzářezová / Double-action pedal harp, Erard frères No. 22

Paříž / Paris, 1817

Celkový pohled, detail s hlavicí a podstavec, fotografie Jan Kř́iženecký / Full view and detailed view of the crown and pedal box, photographs by Jan Kř́žženecký NM-ČMHE 88 
Původ: V „Erard London Harp Ledgers" ${ }^{\text {"56 }}$ je uvedeno, že harfa byla prodána panu Thomsonovi z Liverpoolu v roce $1824 .{ }^{57}$ Do fondu NM se harfa dostala v roce 1961 z pozůstalosti české harfistky, pedagožky a sběratelky Marie Zunové-Skalské (1897-1961).

Srovnatelné exempláře: Museo dell’Arpa Victor Salvi - Sébastien Erard, pedálová harfa dvouzářezová No. 2377, London 1812, 43 strun, $E_{0}-e^{6}, 8$ pedálů (inv. č. SC0700)58; Deutsches Museum München - Sébastien Erard, pedálová harfa dvouzářezová No. 2631, Londýn 1818, 8 pedálů (inv. č. 16147) 59

\section{- Erard frères, pedálová harfa jednozářezová No. 993}

empirový model, Paříž, 1825 (inv. č. E 2004, přír. č. 61/61)

výška $1720 \mathrm{~mm}$, počet strun 43, menzury 80 a $1530 \mathrm{~mm}$, původně 8 pedálů, rozsah $\mathrm{E}_{1}-\mathrm{e}^{4}$

Nápisy: „MÉDAILLES D’OR lers. Prix / Dux Expositions de l Industrie Fr.se / de 1819 \& 1823.“, „ERARD FRERES PAR BREVÊT D’INVENTION No. 993. / Facteurs de Forte Piano \& de Harpes du Roi. / de ses Menus Plaisirs De la Cour Imp ale de Russie. / de S. A. R. Mgr. le Due d’Orléans \& de sa Famille. / Rue du Mail Nos. 13 \& 21 à Paris."

Původ: V Pařiži od Erarda ${ }^{60}$ harfu zakoupil roku 1829 ředitel továrny Johann Jakob Schwartz (1769-1848). ${ }^{61}$ Národní muzeum ji získalo v roce 1961 z fondu pražské konzervatoře. ${ }^{62} \mathrm{Je}$ možné, že se jedná o harfu, kterou daroval roku 1829 mecenáš pražské konzervatoře, hrabě František Josef z Vrtby (1759-1830).

Srovnatelný exemplář: Musée de la Musique Paris - Erard frères, pedálová harfa jednozářezová No. 759, Paříž 1821, 41 strun, 8 pedálů (inv. č. E.984.3.1) $)^{63}$

\section{- Sébastien a Pierre Erard, dvouzářezová pedálová harfa No. 6147 gotický model, Londýn, 1856 (inv. č. E 2003, př. č. 1916/58)} výška 1775 mm, počet strun 46, menzury 115 a 1560 mm, 8 pedálů, rozsah Ces $_{1}-$ fes $^{4}$

56) Royal College of Music v Londýně dnes vlastní tři knihy „Erard London Harp Ledgers” (dále RCM 497), které obsahují důležité informace o výrobě a prodeji Erardových harf vyrobených v Londýně v letech cca 1798-1915. Zůstalo neobjasněno, proč se stejné sériové číslo nachází v archivních knihách jak londýnských, tak i pařížských ( $v$ pařížském záznamu stojí pod č. 3574, že se jedná o gotický model, 46 strun, javor, vyrobeno 8. 4. 1910, prodej 1910 - Félix Lebano Buenos Aires). - Musée de la Musique, dostupné z http://archivesmusee.citedelamusique.fr/pleyel/archives.html

57) Archivní zápis: „Mr Thomson / Bold Street, Liverpool / July 3 1824“ - Erard London Harp Ledgers. MS 10111 Erard Ledger (2) [3565-3574], s. 220. - RCM 497.

58) E-mail od Roberty Scarzello ze dne 15. 2018; RENSCH 2007, op. cit. v pozn. 19, obrazová pŕíloha 10b.

59) Srov. http://www.deutsches-museum.de/de/forschung/forschungsbereiche/wissenschaftsgesch/sonic-visual-exhibit/early-pedal-harp/?sword_list]]=Poulopoulos\&no_cache=1 [cit. 18. 5. 2018].

60) V archivním záznamu stojí: „Grisse Satiné Grand model / 993 / ... Dez. 1825/ 5. Août 1829 / M. Joh. Jakob Schwartz à Vienne (Autriche)". Erard Registres d’Atelier (Renseignés par Numéro de Série), dostupné z http:// archivesmusee.citedelamusique.fr/pleyel/archives.html [cit. 10. 3. 2018].

61) Srov. heslo „Schwarz (Schwartz) von Mohrenstern, Johann Jakob (1769-1848)“ - http://www.biographien.ac.at/oebl/oebl_S/Schwarz-Mohrenstern_Johann-Jakob_1769_1848.xml [cit. 25. 4. 2018].

62) Je možné, že se jedná o harfu, kterou daroval roku 1829 mecenáš pražské konzervatoře, hrabě František Josef z Vrtby (1759-1830). O daru hraběte F. Vrtby se zmiňuje J. Branberger. - BRANBERGER, Jan: Konservatoř hudby v Praze. Pamětní spis k stoletému jubileu založení ústavu, Knihtiskárna „Politiky“, Praha 1911, s. 39; Př́růstková kniha 1951-1965, s. 97 (č. j. 1015/61).

63) Dostupné z http://collectionsdumusee.philharmoniedeparis.fr/doc/MUSEE/0160878/harpe-a-simple-mouvement\# [cit. 23. 4. 2018]. 


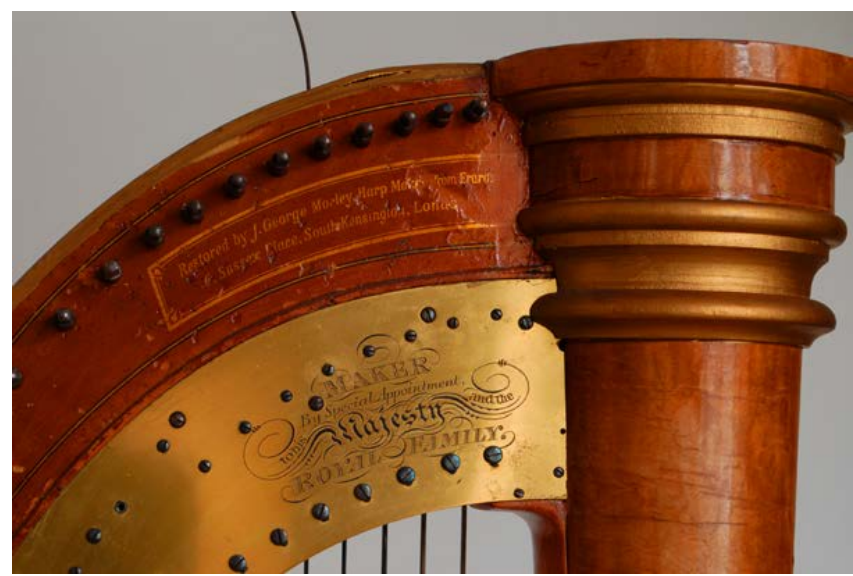

Harfa pedálová dvouzářezová / Double-action pedal harp, Sébastien Erard No. 3574 Londýn / London, 1824

Detail nápisu na krku, fotografie Jan Kříženecký / Detail of inscription on the neck, photograph by Jan Kříženecký NM-ČMH E 1994
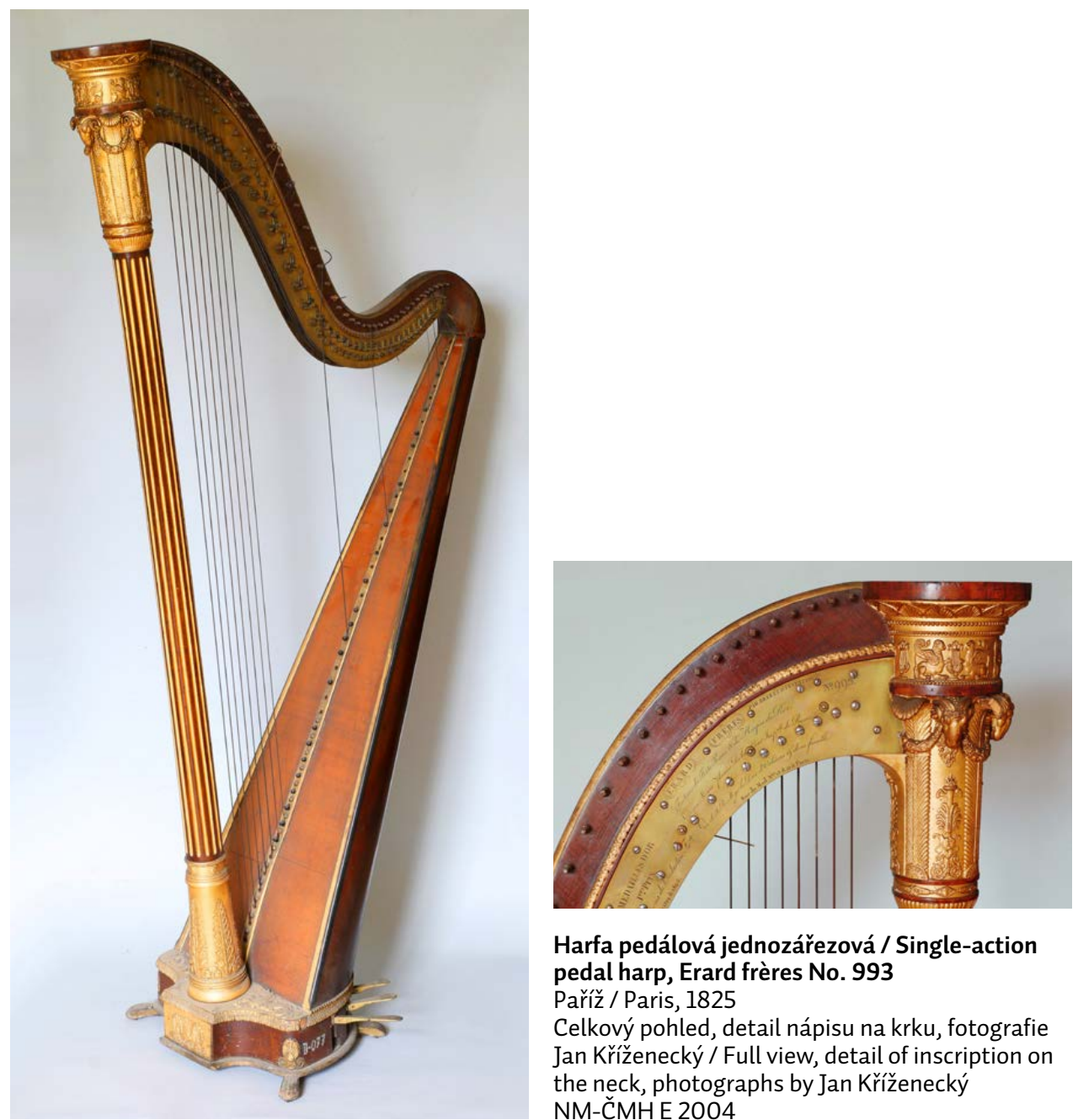

Harfa pedálová jednozárezová / Single-action pedal harp, Erard frères No. 993

Paříž / Paris, 1825

Celkový pohled, detail nápisu na krku, fotografie Jan Krríženecký / Full view, detail of inscription on the neck, photographs by Jan Křriženecký NM-ČMHE 2004 
Nápisy: „Sebastian and Pierre Erards, Patent No. 6147 / 18. Great Marlborourgh Str. London“. Na spodní části podstavce vytištěno „6139 R. B.“ a rukopisný záznam „Ant [?] Germany“.

Původ: Od londýnské pobočky Erard harfu koupila slečna Fox roku $1861 .{ }^{64} \mathrm{~V}$ dalším období nástroj vlastnil český harfista Karel Jirmus (1852-1928), Národnímu muzeu ji roku 1870 daroval jeho otec Václav Jirmus „před odjezdem do Ameriky“. 65

Srovnatelný exemplář: Victoria and Albert Museum - S. \& P. Erard, pedálová harfa dvouzářezová No. 6212, Londýn, 1858, 46 strun, 8 pedálů (inv. č. W.48-1931) ${ }^{66}$

- Erard, dvouřezová pedálová harfa No. 2284

gotický model, Paříž, 1892 (inv. č. E 2425, př. č. 166/84)

výška $1775 \mathrm{~mm}$, počet strun 46, menzury 100 a $1570 \mathrm{~mm}$, počet pedálů 7, rozsah Ces $_{1}-\mathrm{fes}^{4}$

Nápisy: „Erard / PAR BREVET D’INVENTION ... 2284“, „Erard / Facteur de Pianos et Harpes / 13 rue du Mail, Paris."

Původ: Podle pařížské knihy firmy Erard zakoupil nástroj roku $1892^{67}$ český harfista, klavírista, dirigent a skladatel Hanuš Trneček (1858-1914). ${ }^{68} \mathrm{~V}$ roce 1984 ho daroval do NM-ČMH jeho žák Václav Klička (1882-1953). ${ }^{69}$

Srovnatelný exemplář: Berliner Musikinstrumentenmuseum - Erard, pedálová harfa dvouzářezová No. 2247, Paříz 1907,70 výška 1770 mm, 46 strun, 7 pedálů (inv. č. 4923) $)^{71}$

\section{Závěr}

Zatímco například vídeňská nebo berlínská kolekce obsahují pouze jednu Erardovu harfu, ${ }^{72}$ Národní muzeum - České muzeum hudby jich vlastní pět z různých časových období, a proto tak patří k významným sbírkám harf zn. Erard ve středoevropském prostoru.

Sonda do současné úrovně bádání západoevropských zahraničních odborníků k danému tématu upozornila, že český výzkum v tomto směru pokulhává. Ačkoliv se harfy i strunné

64) V archivním záznamu stojí: „6147 / º 1 / Maple Gothic / Oil Gold / April 1856. Sold 30 January 1861 / to Miss Fox, of No 111 / Marine Parade, Brighton" Erard London Harp Ledgers, MS 10112 Erard Ledger 3 [6145-6154] s. 194. - RCM 497.

65) „Nástroje“ - Přírůstková kniha 1948-1961, rok 1958, s. 134; Další podrobnosti viz ŠTĚDROŇ, Bohumír: Jirmus, Karel, in: Československý hudební slovník, 1. díl, Praha 1963, s. 613.

66) Dostupné z http://collections.vam.ac.uk/item/058933/pedal-harp-s-p-erard [cit. 20. 2. 2018].

67) V archivním záznam stojí: „Harpe Style Gothique a 46 cordes / 15 Mai 1892 / 31 Mai 1892 / Mr. Hans Trneček a Prague" - http://archivesmusee.citedelamusique.fr/pleyel/archives.html [cit. 20. 2. 2018].

68) Srov. ČERNUŠÁK, Gracian: Trneček, Hanuš, in: Československý hudební slovník osob a institucí, 2. díl, Praha 1965, s. 790-791.

69) Srov. ŠTĚDROŇ, Bohumír: Klička, Václav, in: Československý hudební slovník osob a institucí, 1. díl, Praha 1963, s. 671-672; Zápis v prírůstkové knize: „L. a V. Kličkovi / U Lužického semináře 10, Praha 1 (dar), 1984“. - Př́růstková kniha 1984-1987, s. 13.

70) Podle pařížských archivních knih byl nástroj dokončen 17. 11. 1891. - Dostupné z http://archivesmusee. citedelamusique.fr/pleyel/archives.html [cit. 31. 5. 2018].

71) DROYSEN-REBER 1999, op. cit. v pozn. 1, s. 252-260.

72) Sammlung alter Musikinstrumente v Kunsthistorisches Museum Wien má dvouzářezovou pedálovou harfu od Erarda (kolem r. 1811, inv. č. SAM 502). Berliner Musikinstrumenten-Museum spravuje Erardovu dvouzářezovou pedálovou harfu (Paříz 1907, inv. č. 4923). Pozoruhodná je sbírka v Deutsches Museum München, která zahrnuje dvě Erardovy pedálové harfy (řecký model No. 2631, Londýn, 1818, inv. č. 16147) a gotický model (Londýn, 1840). 


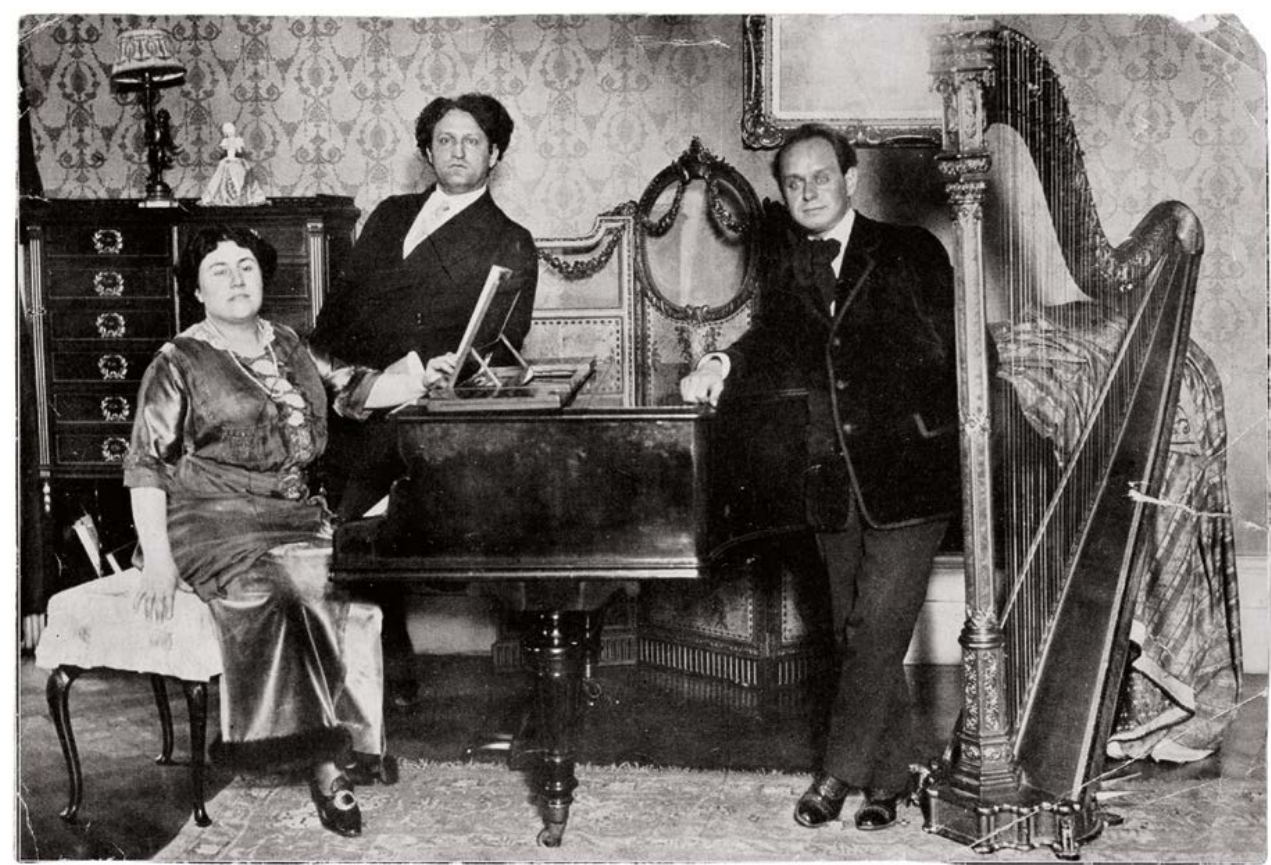

Harfista Václav Klička (1882-1914) s Emou Destinnovou / The harpist Václav Klička (1882-1914) with Emmy Destinn

Zprava: Václav Klička s harfou zn. Erard, za klavírem Ema Destinnová a neznámý muž. Černobílá fotografie novinového výstřižku z německy psaného časopisu, cca 1913 /

From the right: Václav Klička with an Erard harp, behind the piano Emmy Destinn and an unknown man. Black-and-white photograph of a newspaper clipping from a German-language journal, ca. 1913 NM-ČMH, pozůstalost Václava Kličky / estate of Václav Klička

klávesové nástroje od Erarda na území dnešní České republiky vyskytují nejen ve sbírce pražského Národního muzea, je překvapující, že o výrobci není dostatek informací v češtině. Nové možnosti případného výzkumu českých badatelů otevírá online přistup do Erardova archivu, který je ve srovnání s jinými výrobci hudebních nástrojů daného období mimořádně bohatý a zachovalý. ${ }^{73}$

Erardovy harfy ze sbírky NM-ČMH dokumentují český sociálně-kulturní kontext, v němž se uplatnil nástroj známé pařížské firmy. Hrálo se na něj v prostředí vzdělanecké společnosti v Praze kolem poloviny 19. století, nejméně jeden sbírkový předmět tvořil součást instrumentáře $\mathrm{k}$ výuce na pražské konzervatoři. Nejnovější Erardovy modely vlastnily a užívaly osobnosti českého výkonného umění konce 19. až první poloviny 20. století (Hanuš Trneček, Karel Jirmus, Václav Klička nebo Marie Zunová-Skalská).

Ačkoliv byl Sébastien Erard dlouhou dobu, částečně až dodnes, považován za „vynálezce“ dvouzářezové pedálové harfy, organologický výzkum posledních let potvrdil, že na

73) Nabízí se například vysledování „české stopy“ v této dokumentaci. Výsledky bádání by přispěly mimo jiné ke studiu profilu Erardova zákazníka z pohledu sociálního i geografického. Podrobnosti k otázce ekonomických mechanismů a strategií, které Erard používal, viz GUILLAUME-CASTEL 2017, op. cit. v pozn. 26. 
zdokonalení konstrukce a funkcí pedálové harfy pracovali už před ním jiní harfaři. Ve své tvorbě Erard navázal na dílo G. Cousineaua a Ch. Grolla a stal se nejúspěšnějším producentem dvouzářezové pedálové harfy s vidličkovou mechanikou (mécanique à fourchettes et à double mouvement). Zhruba od poloviny 19 . století už zůstávají tvar nástroje i menzury strun u koncertní harfy stejné, pouze dekorace nástroje se obměňuje ve všech stylech. ${ }^{74}$ Erardův "gotický" model (například harfu No. 2284, inv. č. E 2425) kopírovali mnozí další výrobci. Své napodobitele i konkurenty měl po celé Evropě, v Čechách na jeho práci navázal velmi úspěšně český harfař Alois Červenka (1858-1938). V dobovém tisku z konce 19. století se dokonce ozývaly názory, že Červenkova harfa předčí harfu Erardovu silou hlasu a výjimečnou čistotou ladění. ${ }^{75} \mathrm{~V}$ těchto souvislostech je třeba reflektovat Erardovo nástrojařské dílo a zdůraznit jeho význam nejen pro historický vývoj harfy, ale také jeho vliv na tvorbu dalších výrobců hudebních nástrojů.

Adresa: Daniela Kotašová, České muzeum hudby, Karmelitská 2, 11800 Praha 1, Česká republika

E-mail: daniela_kotasova@nm.cz

74) WOLF, op. cit. v pozn. 19, s. 4.

75) Pan Alois Červenka, Dalibor, roč. 12, 1890, č. 47, (13. 12.), s. 374. Další podrobnosti, zejména k hlavnímu rozdílu ve stavbě Erardovy a Červenkovy mechaniky viz KOTAŠOVÁ, Daniela: Alois Červenka a jeho harfy ve sbírce Českého muzea hudby, Opus musicum, roč. 49, 2017, č. 3, s. 16-17. 